\title{
REVIEW OF CURRENT PRACTICE IN CHARACTERIZATION AND MONITORING
}

\author{
Principal Investigator: \\ M. A. Ebadian, Ph.D. \\ Florida International University \\ Collaborators: \\ Hans Weger
}

Hemispheric Center for EnVIRonmental TeChnology (HCET)

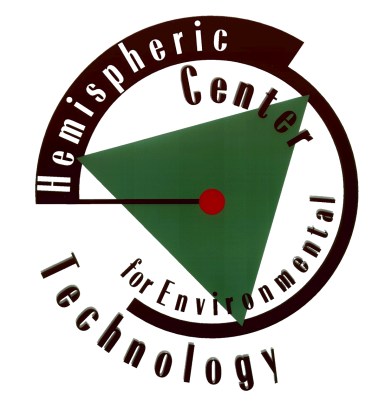




\section{DISCLAIMER}

This report was prepared as an account of work sponsored by an agency of the United States government. Neither the United States government nor any agency thereof, nor any of their employees, nor any of its contractors, subcontractors, nor their employees makes any warranty, express or implied, or assumes any legal liability or responsibility for the accuracy, completeness, or usefulness of any information, apparatus, product, or process disclosed, or represents that its use would not infringe upon privately owned rights. Reference herein to any specific commercial product, process, or service by trade name, trademark, manufacturer, or otherwise does not necessarily constitute or imply its endorsement, recommendation, or favoring by the United States government or any agency thereof. The views and opinions of authors expressed herein do not necessarily state or reflect those of the United States government or any agency thereof. 


\title{
Principal Investigator
}

M.A. Ebadian, Ph.D.

Hemispheric Center for Environmental Technology

Florida International University

Miami, FL 33174

\section{Florida International University Collaborators}

\author{
Hans Weger \\ Hemispheric Center for Environmental Technology \\ Florida International University \\ Miami, FL 33174
}

January 2001

\section{Prepared for}

U.S. Department of Energy

Office of Environmental Management

Office of Science and Technology

U.S. Department of Energy

Under Grant No.: DE-FG21-95EW55094 


\section{ACKNOWLEDGMENTS}

This report is based on work supported by the U.S. Department of Energy, Office of Environmental Management, Office of Science and Technology's Deactivation and Decommissioning Focus Area, National Energy Technology Laboratory (NETL). The Principal Investigator, the Florida International University (FIU) Collaborators, and students at FIU would like to thank Dr. Paul Hart, Robert Bedick, and Steve Bossart for providing us with support and the opportunity to work on this project. In addition, FIU-HCET would like to thank Consumers Energy's personnel for collaborating in this demonstration and providing the Big Rock Point as the hosting demonstration site. 


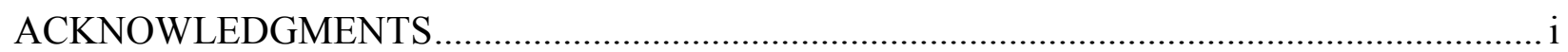

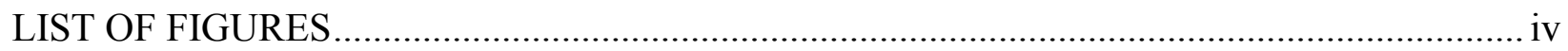

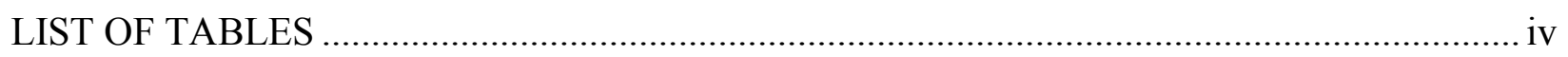

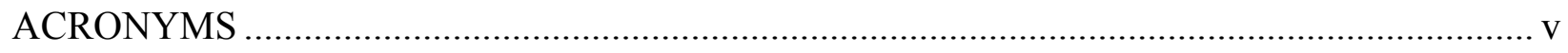

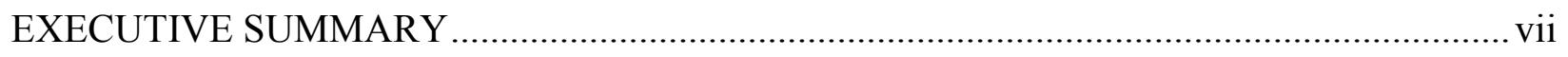

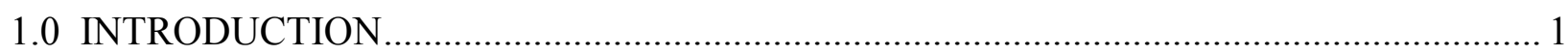

2.0 DATA ASSESSMENT METHODOLOGY …................................................................ 2

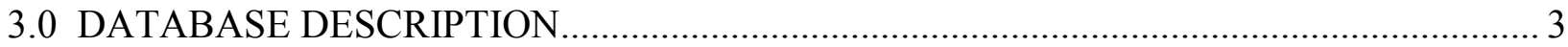

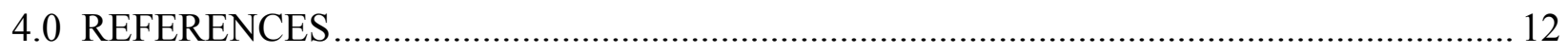




\section{LIST OF FIGURES}

Figure 1. The login page is the main page of the database. .................................................. 4

Figure 2a. The database map has different links that take the user to the Site Technology Group (STCG) Needs table or the Baseline Technology table. 4

Figure $2 \mathrm{~b}$. This is the bottom part of the database map, showing the Search links and the Visitor Utility links of the database.

Figure 3. Only one screen length of the STCG Need table for the DDFA is shown. The underlined text serves as a link to the respective record for either the description of the need number or of the baseline technology. 5

Figure 4. Only one screen length of this record for a specific STCG Need is shown.

Figure 5. Only one screen length is shown of this record of a specific baseline technology with the description.

Figure 6. Only one screen length is shown of the Baseline Technology table for the baseline technologies for the DDFA. The underlined text serves as a link to the respective record for either a description of the STCG need number or the baseline technology.

Figure 7. The user is allowed to choose the Baseline Technology of interest from the list that can be viewed by clicking on the down arrow to the right of "Select a baseline technology.".... 7

Figure 8. This screen allows the user to make a selective search for STCG Needs or Baseline Technology. The database asks for the field and the search string. 8

Figure 9. This is the screen for the General Search for either STCG Needs or Baseline Technology.

\section{LIST OF TABLES}

Table 1. The Seven Database Tables 


\section{ACRONYMS}

CMST-CP Characterization, Monitoring , and Sensor Technology - Crosscutting Program

DDFA Deactivation and Decommissioning Focus Area

DOE Department of Energy

EM Environmental Management

FIU Florida International University

FY Fiscal Year

HCET Hemispheric Center for Environmental Technology

INEEL Idaho National Engineering and Environmental Laboratory

MWFA Mixed Waste Focus Area

NMFA Nuclear Material Focus Area

ORR Oak Ridge Reservation

SCFA Subsurface Contamination Focus Area

SRS Savannah River Site

STCG Site Technology Coordination Group

TFA Tanks Focus Area 


\section{EXECUTIVE SUMMARY}

This two-year project had the goal of creating a database containing cost and performance data on baseline characterization and monitoring technology used at Department of Energy (DOE) sites. This database will facilitate the direct comparison of innovative technology to the current practice or baseline technology. The Site Technology Coordination Group (STCG) need statements were reviewed for characterization and monitoring needs for the DOE sites at Hanford, Oak Ridge Reservation, (ORR), Idaho National Engineering and Environmental Laboratory, (INEEL), and the Savannah River Site (SRS). The baseline technologies were identified from these need statements. Cost and performance data for each baseline technology was obtained, evaluated, and entered into the database. The Current Practice database is accessible to the Characterization, Monitoring Sensor, and Technology - Crosscutting Program (CMST-CP) and others at the Internet address $<\mathrm{http} / / / 131.94 .165 .121 / .>$ Access to this database from the CMST-CP webpage can be accomplished by the use of a link. 


\subsection{INTRODUCTION}

Characterization and monitoring are important parts of environmental remediation of contaminated sites by the Department of Energy - Office of Environmental Management (DOEEM). The actual remediation process often cannot begin or even be planned until characterization is complete. Monitoring is essential to verify the progress of remediation and of the waste stream. However, some contaminated sites are difficult, costly, or have a high exposure risk to personnel to characterize or monitor using the baseline technology or current practice. Therefore, development of new characterization and monitoring technologies is time-critical to remediate these sites.

The main task of the Characterization, Monitoring, and Sensor Technology Crosscutting Program (CMST-CP) is to develop and deploy innovative characterization and monitoring technologies that improve performance and reduce personnel exposure, cost, and detection limits. However, to evaluate different proposals for new technologies to decide which ones to develop or deploy, it is necessary to compare their cost and performance to the baseline technology. The goal of this project is to facilitate the direct comparison of new technologies to the baseline technology by documenting the current practices for site characterization and monitoring at DOE sites and by presenting the information in an easy-to-use, concise database. The database will assist the CMST-CP and others in evaluating or designing new technologies by identifying the baseline technologies and describing their performance and cost.

The characterization and monitoring need statements published by the Site Technology Coordination Groups (STCGs) of each site were used to identify the baseline technologies that are, in some manner, insufficient and need to be replaced with new technologies. Baseline technologies that perform satisfactorily and do not need replacement are not evaluated for the database. Cost and performance data of each baseline technology identified was obtained through documents, vendors, site personnel, and experts. The data was evaluated and tabulated into a database. The sites investigated were Hanford, Oak Ridge Reservation (ORR), Savannah River Site (SRS), and the Idaho National Engineering and Environmental Laboratory (INEEL). This database was placed on the Internet at $<$ http://131.94.165.121/>, allowing the CMST-CP and others to access it. Access to this database from the CMST-CP webpage can be accomplished by the use of a link.

The database contains tables concerning the STCG needs and the identified baseline technologies. Continual discussions concerning the project and the database with CMST-CP personnel were held throughout FY99 and FY00. A prototype database was presented at the 1999 CMST-CP Mid-Year Review at Gaithersburg, Maryland, on March 9-10, 1999. The database was demonstrated to several representatives from the Decontamination and Decommissioning Focus Area and from CMST-CP who visited FIU-HCET throughout the duration of the project.

The purpose of this document is to report on the completion of this project and to describe the database. Section 2.0 describes the data assessment methodology. Section 3.0 presents the database and serves as a user manual. Section 4.0 lists the references used for each baseline technology in the database. The full references can be found in the Appendix. 


\subsection{DATA ASSESSMENT METHODOLOGY}

The first step in this project was to identify the baseline technologies. The goal was to concentrate on the baseline technologies that had been identified as being inadequate in some aspect of site characterization or monitoring and required replacement with a new technology. Therefore, the STCG needs were reviewed for characterization and monitoring needs for four of the largest, more complex DOE-EM sites: Hanford, ORR, INEEL, and SRS. The STCG need statements list the baseline technologies used at the sites. Some need statements were ambiguous and required further investigation to identify the baseline technology. Sixty-three baseline technologies were identified.

After identifying the baseline technologies, research into the cost and performance data began. Information was obtained from many sources(listed in section 4.0), evaluated, and then tabulated. Information was obtained from DOE documents, vendors, site personnel, and experts. Unfortunately, many requests for information from site managers and end-users at the sites were unanswered. In such cases, data had to be obtained from documentation written by site managers and end-users about their work. A vast majority of these documents are available on the DOE website "DOE Information Bridge" at <http://www.osti.gov/bridge/ $>$ as an Adobe Acrobat file.

All the data was combined and compacted into several paragraphs. Concise descriptions were written for each technology, and the data was divided into two categories: performance and cost estimates. The performance capabilities were divided into the categories: ability to meet STCG need, time, waste, detection limit, and personnel exposure. The cost estimates included, when available, capital, maintenance, and operational costs.

The cost estimates for many of the baseline technologies were hard to generalize. Some technologies have a wide range of capital cost depending on the desired capabilities of the machine or instrument. Other technologies had a wide range of operational costs depending on the terrain, obstacles, required detection limit, and other factors. Costs obtained from different sources also had a variation in the dollar amount. Therefore, costs are often given as a range. Operational costs are given as dollars per foot, per square foot, per sample, per hour, or other unit. Subsite specific costs are not obtainable since each subsite has specific characteristics that change the cost, and each site contains numerous subsites. 


\subsection{DATABASE DESCRIPTION}

\subsection{USER INFORMATION}

The Current Practice Database can be accessed at the Internet address $<$ http://131.94.165.121/>, which is the login page. No domain name has been registered for the database. Users enter their login name and are sent to the database map; however, new users are required to enter some information (name, company name, and e-mail address) to obtain a login name (see Figure 1). The database map is a web page with several links that allow the user to access the information. The database map contains four divisions: the STCG Needs, Baseline Technology, Search, and Visitor Utility (see Figures $2 \mathrm{a}$ and $2 \mathrm{~b}$ ).

The STCG Needs are categorized (see Figure 2a) either by Focus Area -Decontamination and Deactivation (DDFA), Subsurface Contamination (SCFA), High Level Waste (HLW), Tanks (TFA), Mixed Waste (MWFA), and Nuclear Materials (NMFA)- or by DOE site (ORR, Hanford, INEEL, and SRS). The STCG Needs table has three columns: the need number, the title of the need number, and the baseline technology identified for that need (see Figure 3). The need number is a link that takes the user to the information on that specific need, which contains the STCG need name, STCG need number, description, requirements, regulation, baseline technology, site location, and focus area (see Figure 4). Moreover, the baseline technology name is a link that takes the user to the specific baseline technology table, which contains the baseline technology name, STCG need number, purpose, description, cost data, ability to meet STCG needs, time, waste generated, detection limit, personnel exposure area, and comment (see Figure 5).

The Baseline Technology section in the database map divides the technologies into focus areas and also has a "view all" option (see Figure 2b). The baseline technology table for each focus area has three columns: the baseline technology name, purpose, and the STCG need number(s) that identified this technology (see Figure 6). The baseline technology name takes the user to the same link as the baseline technology name in the STCG needs table. The purpose tells the user the use of this technology and does not serve as a link. The STCG need number takes the user to the information table for that specific STCG need number in the same manner as the STCG table. The View All option brings the user to a list of all the baseline technologies and allows the user to chooses the specific technology to view (see Figure 7).

In the search section of the database map, the user is presented with tools that search the database. The Selective Search has an option to choose either STCG Needs or the Baseline Technology and then sends the user to a page to choose the field area (such as "description," "cost," or "personnel exposure") and to write the search string in a blank box (see Figure 8). The other search option is the General Search, which allows the user to search for a word or phrase (the search string) among the entire text of the STCG Need or Baseline Technology text (see Figure 9).

The Visitor Utility has different links with a variety of options. It has the text of the database in Microsoft Word format (and can be downloaded), Member E-mail, Event Board, Post a Question, Member Chat, and Last 10 Visitors (see Figure 2b).

There is also a link that connects the user to the Home page or the login page. Other sidebar links are Description of the Database, Acronyms, About Us, Contact Us, Disclaimer, Links, and STCG Need Notes. 


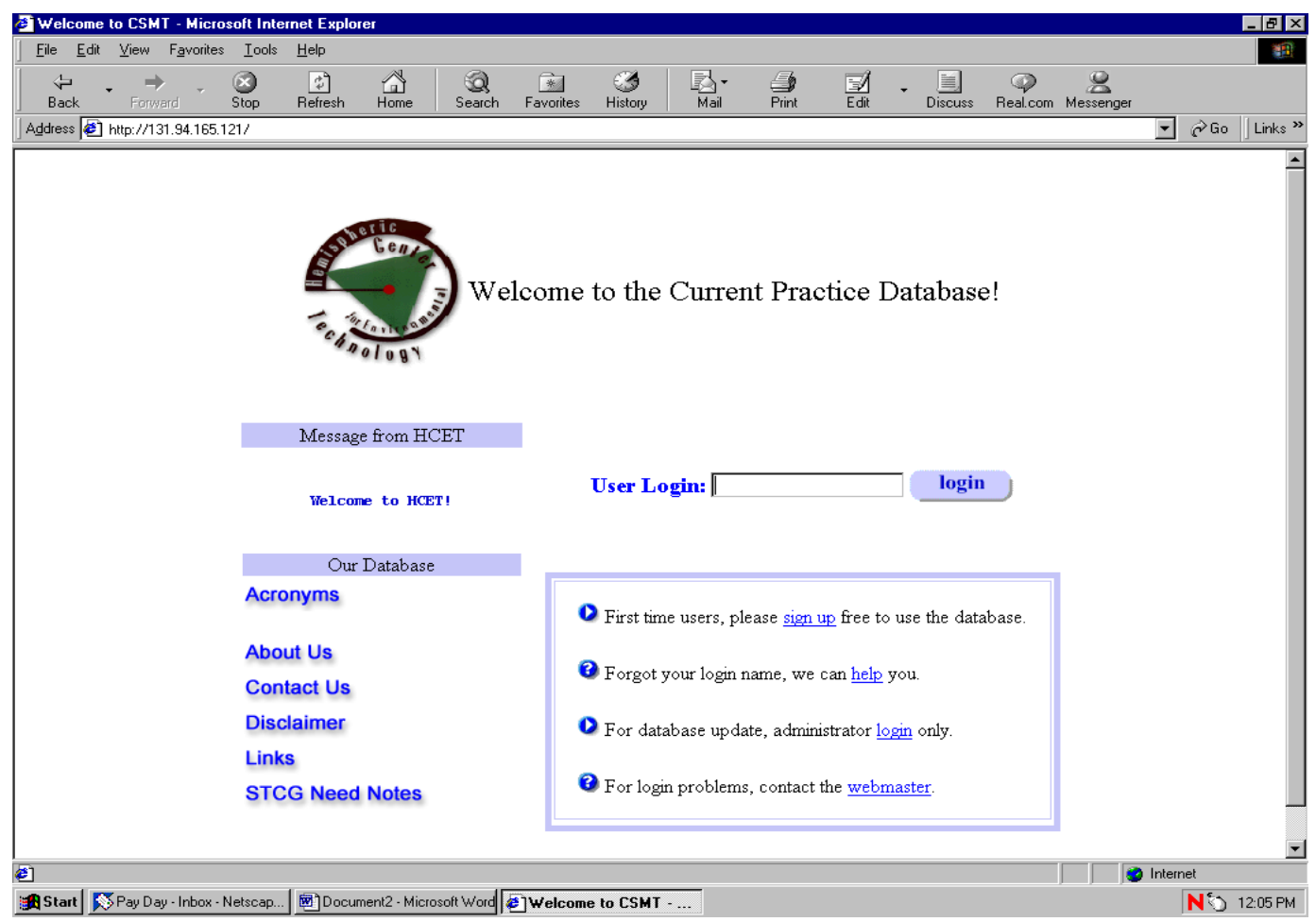

Figure 1. The login page is the main page of the database.

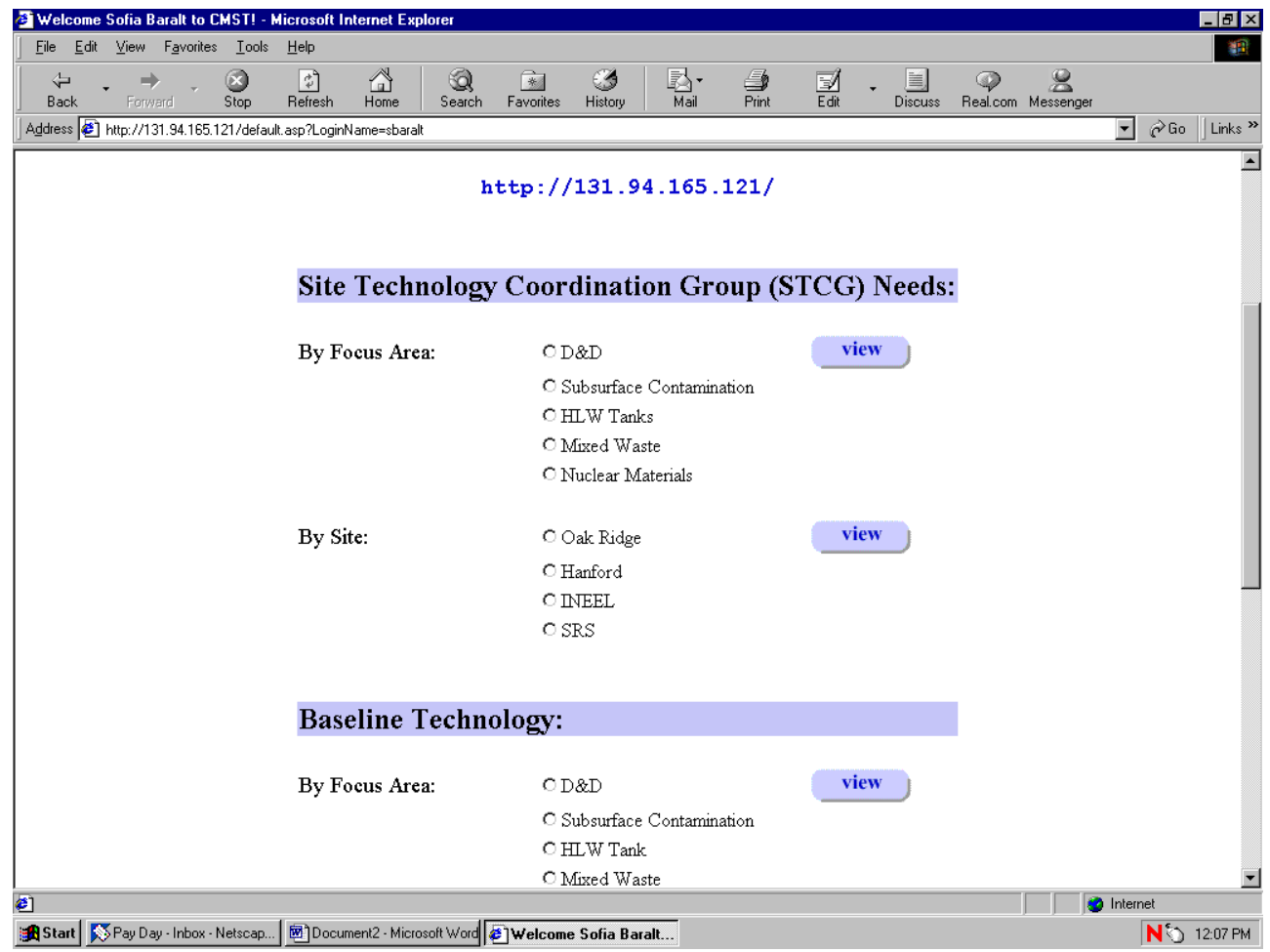

Figure 2a. The database map has different links that take the user to the Site Technology Group (STCG) Needs table or the Baseline Technology table. 


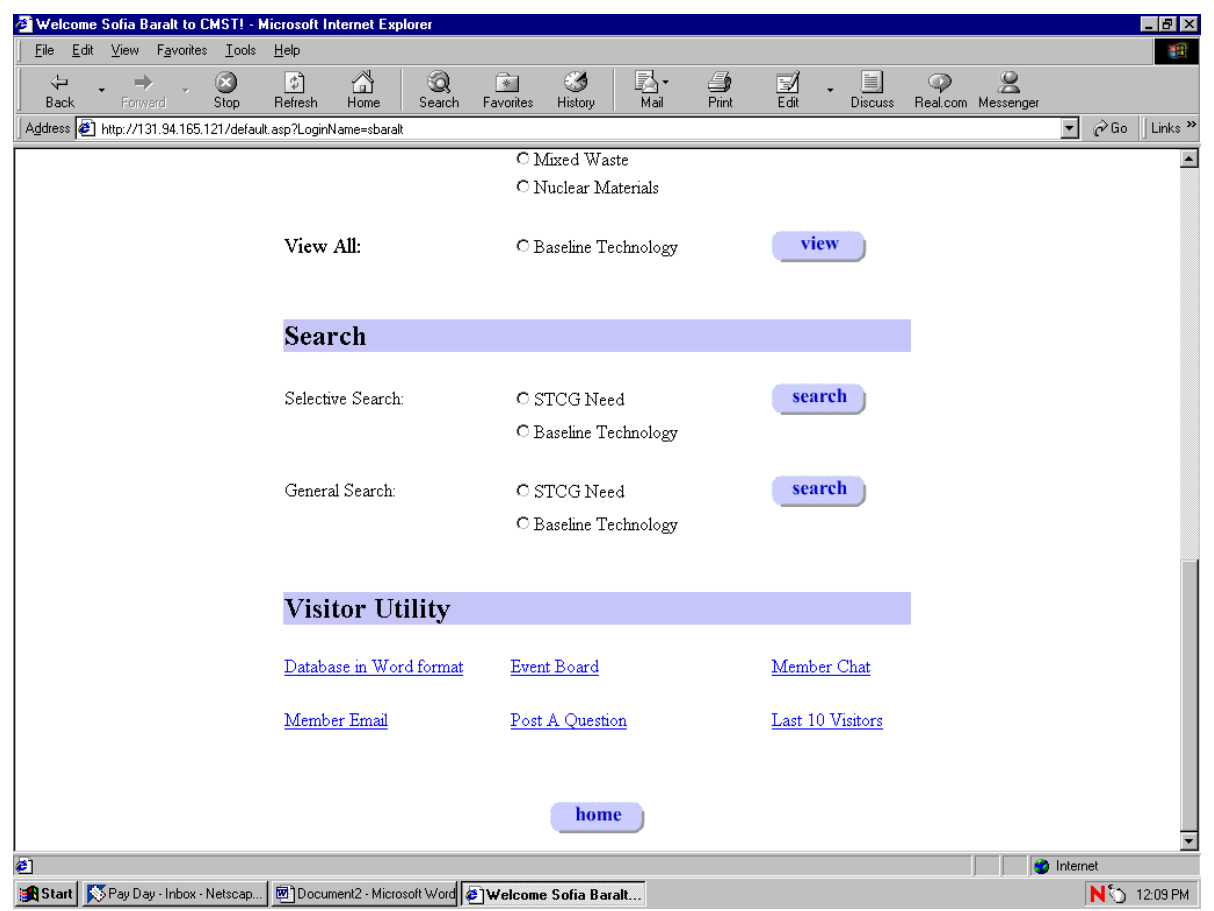

Figure 2b. This is the bottom part of the database map, showing the Search links and the Visitor Utility links of the database.

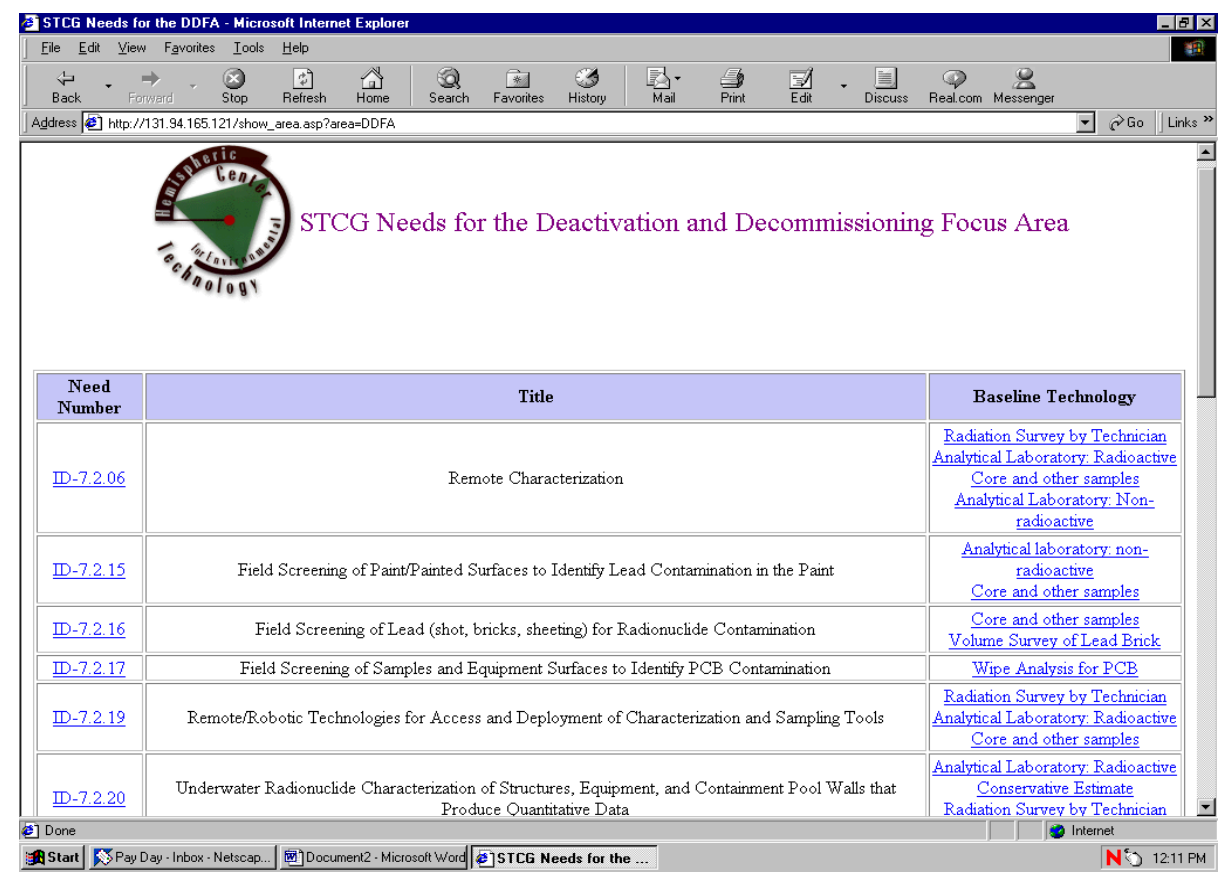

Figure 3. Only one screen length of the STCG Need table for the DDFA is shown. The underlined text serves as a link to the respective record for either the description of the need number or of the baseline technology. 


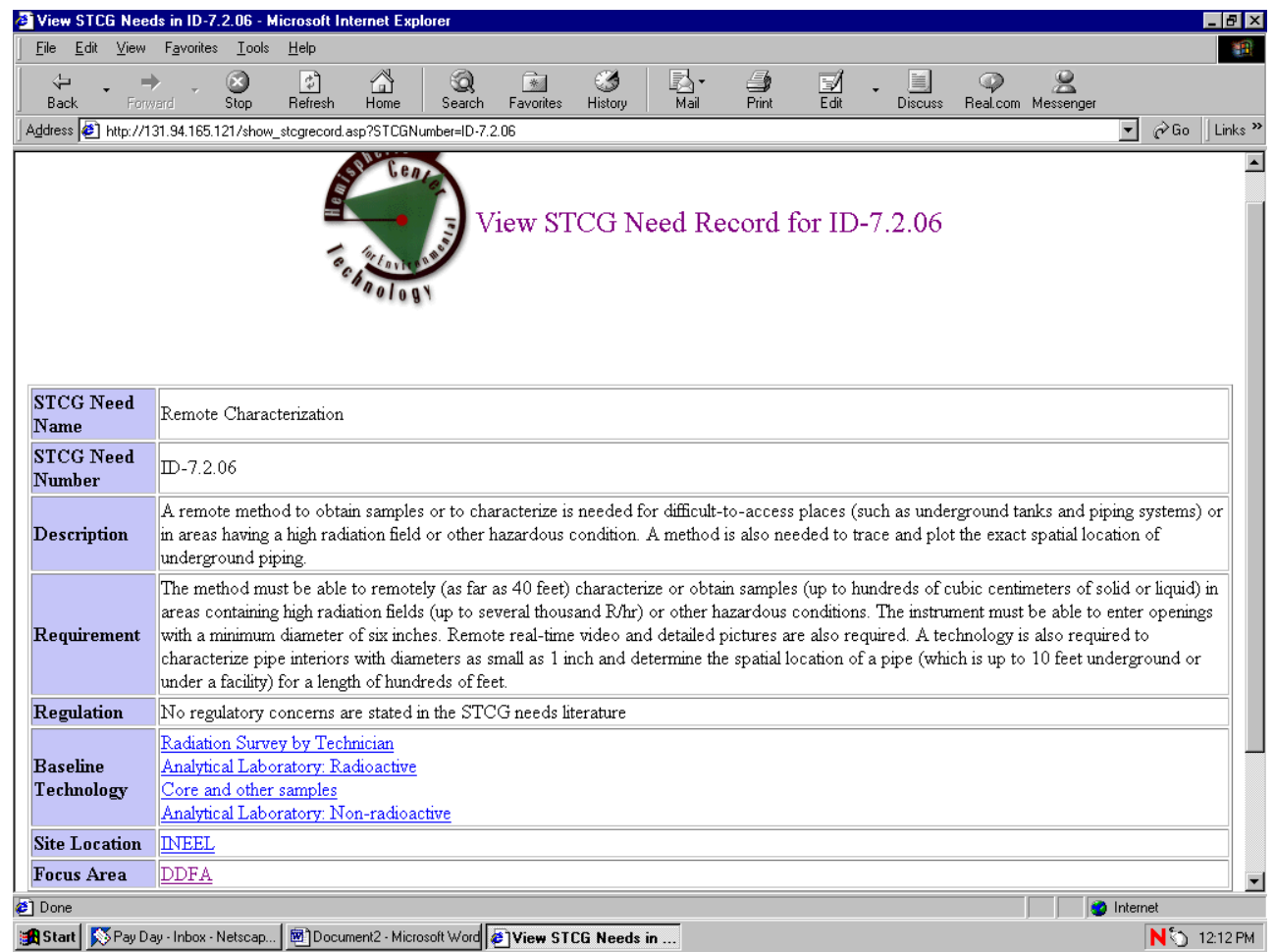

Figure 4. Only one screen length of this record for a specific STCG Need is shown.

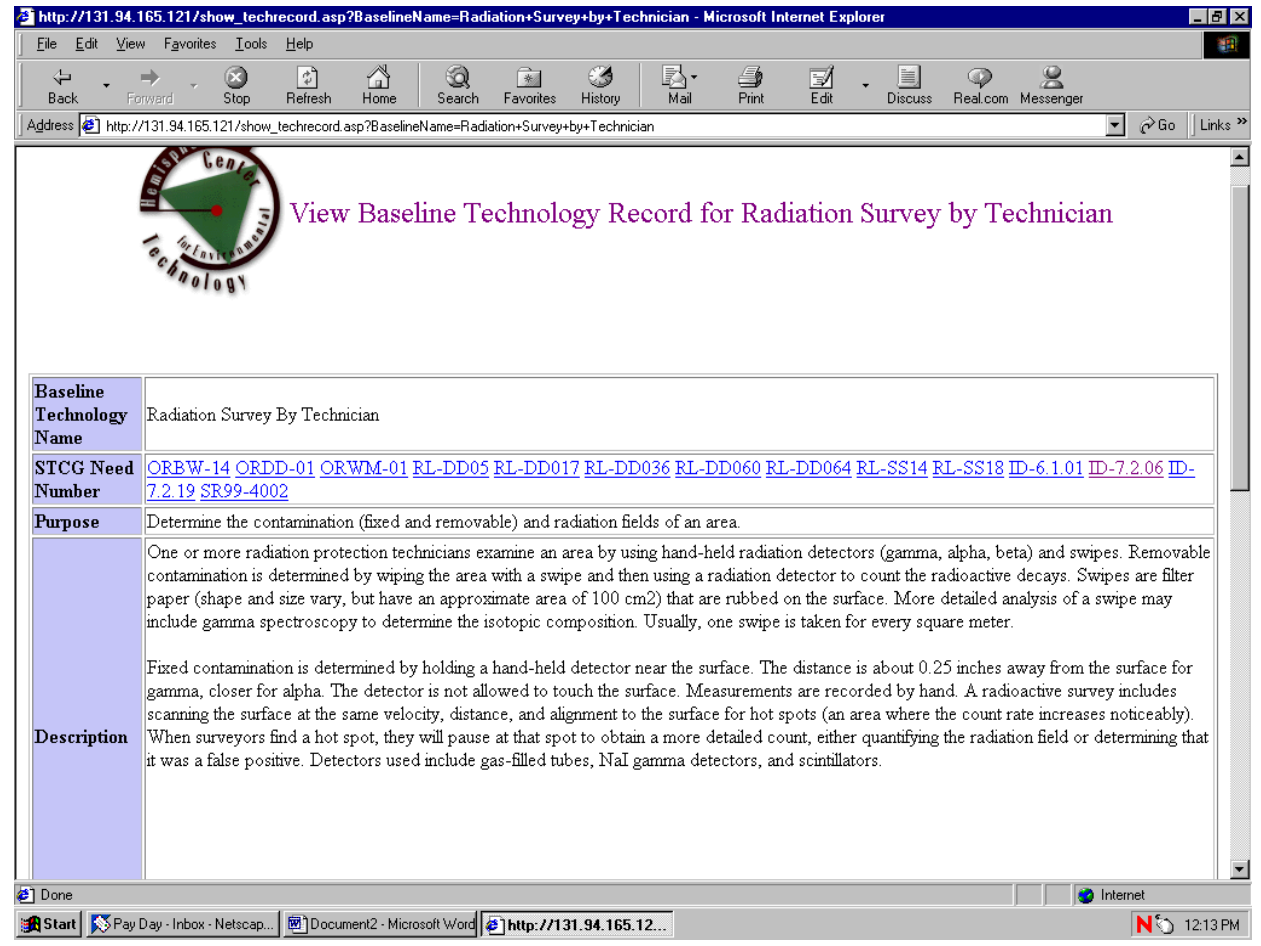

Figure 5. Only one screen length is shown of this record of a specific baseline technology with the description. 


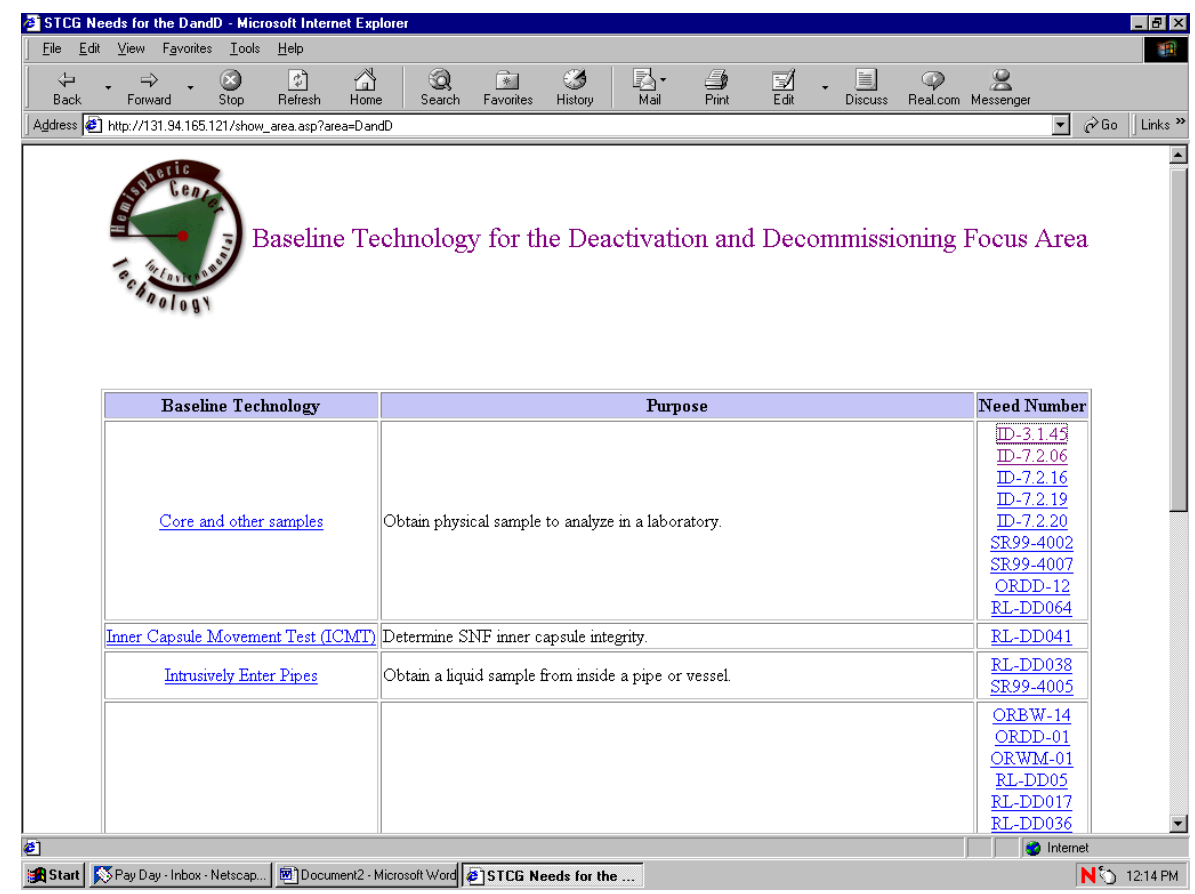

Figure 6. Only one screen length is shown of the Baseline Technology table for the baseline technologies for the DDFA. The underlined text serves as a link to the respective record for either a description of the STCG need number or the baseline technology.

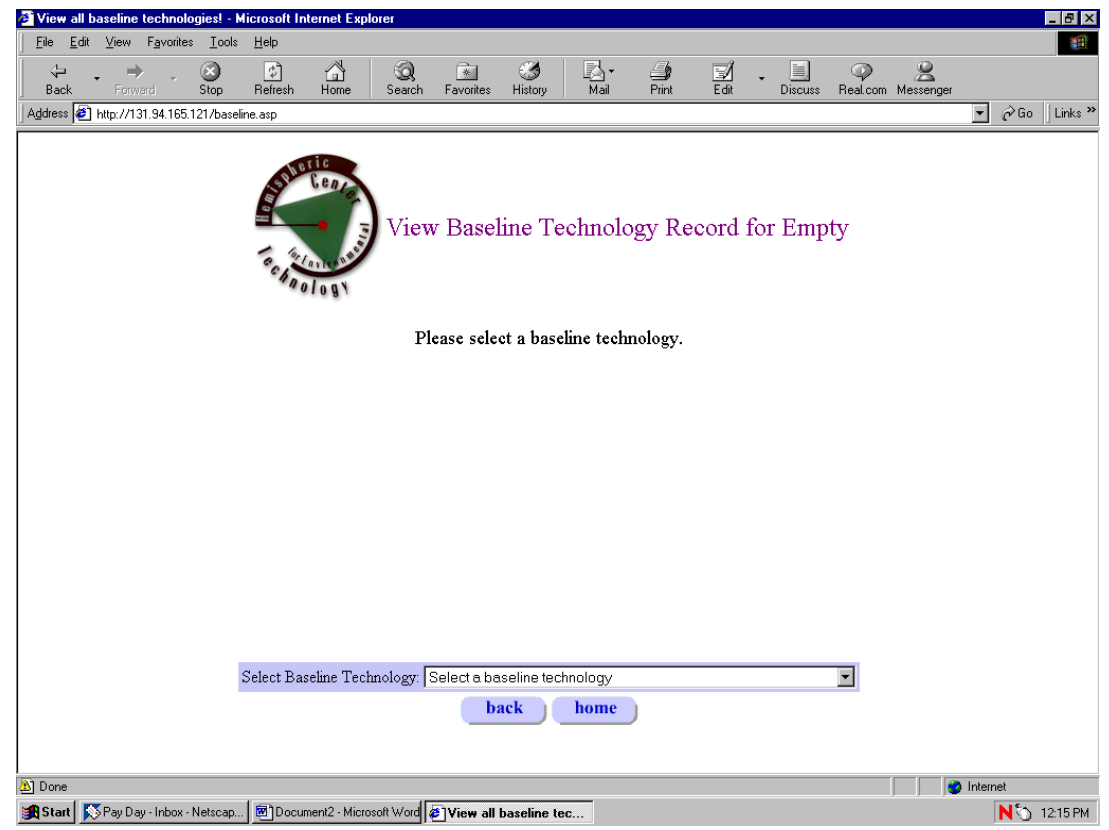

Figure 7. The user is allowed to choose the Baseline Technology of interest from the list that can be viewed by clicking on the down arrow to the right of "Select a baseline technology." 


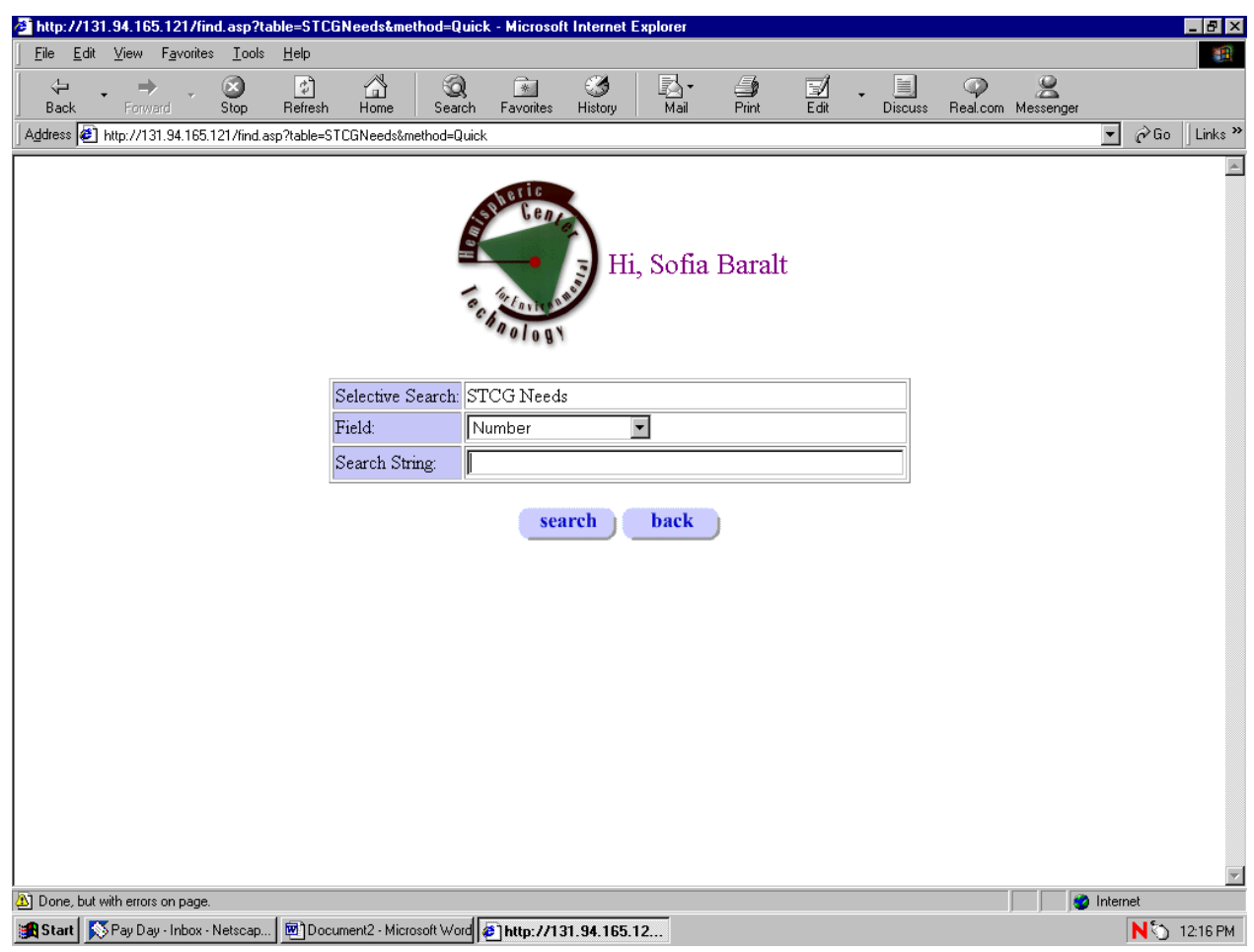

Figure 8. This screen allows the user to make a selective search for STCG Needs or Baseline Technology. The database asks for the field and the search string.

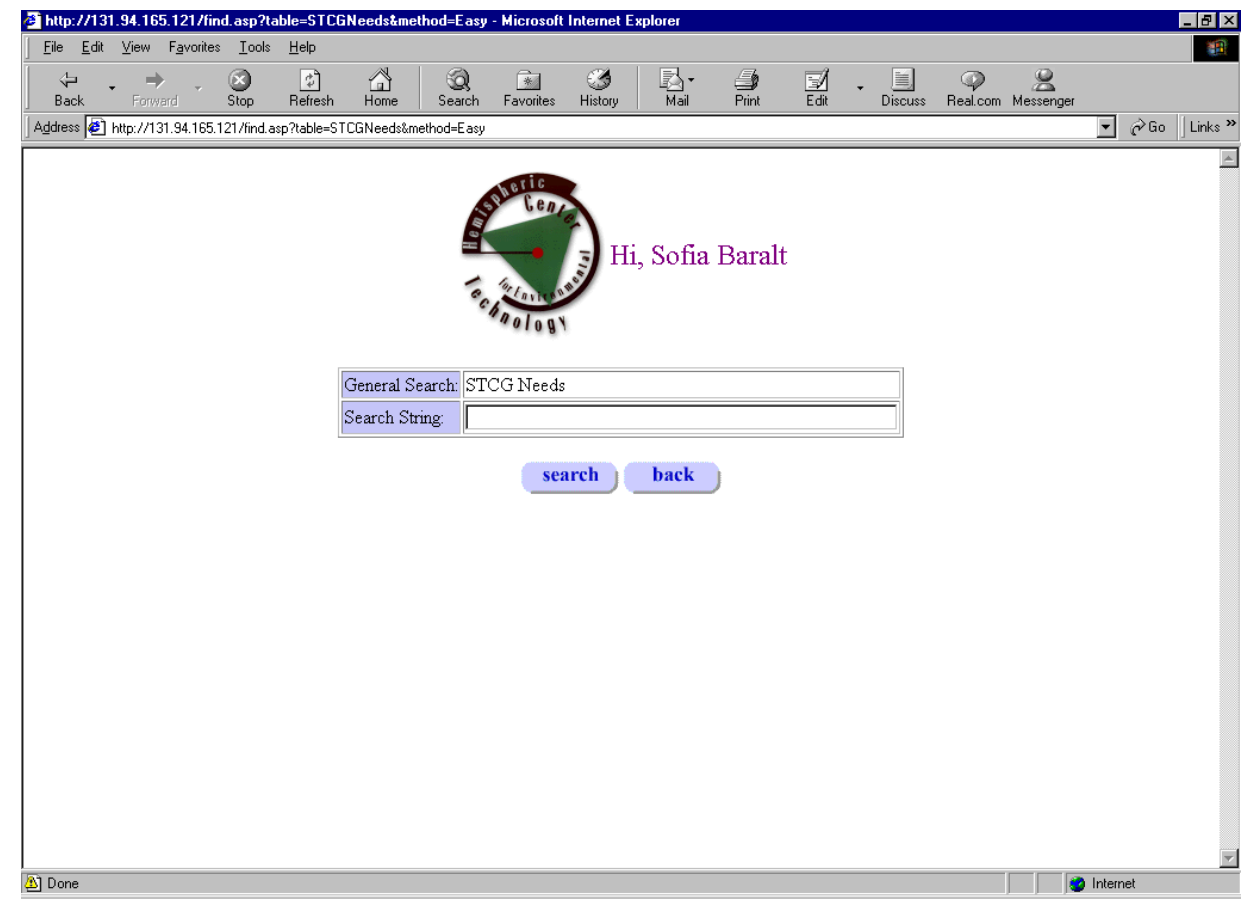

Figure 9. This is the screen for the General Search for either STCG Needs or Baseline Technology. 


\subsection{TECHNICAL INFORMATION}

No domain name has been registered for this database; therefore, the user has to type the IP address to access the Current Practice Database. Access to this database from the CMST-CP web page can be accomplished by the use of a link. Microsoft SQL Server version 6.5 is used to manage the database and Microsoft Active Server Page (ASP version 2.0) is the main software to write all server side script files. One of the features ASP provides is that the third party, independent software companies, could offer specially designed software components to accomplish a specific task such as automated e-mail responder and file upload. These software components are written for the Windows NT system. ASPSMART®, a shareware program distributed by DIMAC AB, was incorporated into the server side scripts to provide a better web page functionality.

\subsubsection{User functions}

The web page is the online user interface that provides information to the users and web page administrator. The Current Practice database interface consists of two major parts, user interface and the administrator interface. Eleven user functions are implemented under the user interface and are described in section 3.1. The sign up function registers users with information they provide. Information such as user name, login name, and e-mail address are stored in the database table Users. User registration is requested to know who is using the database and to build a better relationship with them for the purpose of improving the database. Furthermore, other functions like Stats could help FIU-HCET gather useful information about web page traffic and design better web pages.

The retrieve function helps users who forgot their login name. This is a typical function implemented for the user's convenience. The login function verifies the registered user login name. More importantly, this function is combined with other functions to gather information about web traffic and to send greetings to individual users by personalizing the web pages the ASP server sends to users. The display function displays all STCG needs and baseline technologies in different focus areas or sites. Every individual STCG need or baseline technology is stored in the database tables. The database in word format function provides Microsoft Word files that contain all the individual STCG needs or baseline technologies. After the user clicks on the links, a free file in Microsoft Word format is downloaded to the user's machine.

The search function provides a means for users to search for specific STCG needs or baseline technologies. The user has two choices to search for an individual record, selective search or general search. Both search methods require the user to enter a phrase, word(s), or letter(s). When the database server finds the matches, the script highlights the matched phrase, word(s), or letter(s) with bold font and red color in the returned web pages. Selective search method requires the user to enter one more search criteria, one of the table fields. Thus, this method has a shorter search time. General search method requires minimum user input but has a longer searching time.

The event board function allows the registered users to post upcoming academic events online. This function is designed mainly for the user community. The member chat function gives the registered users a means to discuss the academic topic online. The member e-mail function is designed for the internal e-mail system. Only registered users may send documents or e-mails to 
other registered users. The post a question function allows the registered users to post academic questions online so that other registered users might post the solution online. The last 10 visitors function records information on the last 10 visitors. This function shows visitor's browser type, IP address, visiting time, and other information. The main purpose of this function is to provide statistics for web page designers.

\subsubsection{Administrator functions}

Six functions are implemented under the administrator interface. The authentication function is the only invisible function implemented and verifies that only authorized people can have access to the functions that insert, modify, or delete records in the database. This function is called before the calls any other administrator function.

The view records in the tables function displays all the data fields in the tables. Fields hidden from the user interface will be displayed under this function. the web designer or the administrator may monitor all the data tables in the database. The add new records to tables function allows authorized people to add STCG needs or baseline technologies to the database. The change administrator password function allows the web designer and the web administrator to change their passwords for security reasons.

The update records in tables function has two sub-functions. One is written for a general update of individual records for an STCG need or baseline technology. With this function, authorized users can only update one record at a time. The other function is implemented to search the database and modify the focus area for all records that match the criteria set up by the authorized users. The delete records in tables function allows the authorized users to delete individual records in different tables.

\subsubsection{Database tables}

Seven database tables are established in the SQL server, namely Administrator, Baseline, Event, Question, Stats, STCGNeeds, and Users (see Table). Table Administrator is set up to store login name and password for authorized web page administrators. Table Baseline is set up to store individual records of baseline technologies. Table Event is set up to store information about upcoming academic events posted by the registered users. Table Question is set up to store questions posted by the registered users. Table Stats is set up to store visitor information. Table STCGNeeds is set up to store records of STCG needs. Table Users is set up to store information on registered users. Only registered users can have access to the user interface. 
Table.

The Seven Database Tables

\begin{tabular}{|l|l|l|}
\hline Table Name & \multicolumn{2}{|c|}{ Table Fields } \\
\hline Administrator & LoginName & Password \\
\hline Baseline & BaselineName & CostData \\
& NeedNumber & Needs \\
& Purpose & Time \\
& Description1 & Waste \\
& Description2 & Limit \\
& Description3 & Exposure \\
& Description4 & Area \\
& Description5 & Comment \\
\hline Event & ID & Location \\
& Poster & Time \\
& Event & \\
\hline Question & ID & Reply_By \\
& Post_By & Answer \\
& Question & Reply_Time \\
& Post_Time & \\
\hline Table Name & & Table Fields \\
\hline Stats & First_Name & Time \\
& Last_Name & ID \\
\hline STCGNeeds & Browser & Regulation \\
& STCGNumber & Baseline \\
& Name & Location \\
& Description & Area \\
\hline Rsers & LoginName & Email \\
& FirstName & Company \\
& LastName & \\
\hline
\end{tabular}




\subsection{REFERENCES}

\subsection{REFERENCES BY TECHNOLOGY}

The references used to obtain the descriptions, performance data, and cost estimates for each baseline technology are presented below. The full references are available in the Appendix. Information for the STCG needs was obtained directly from the STCG need statements published on the DOE site's STCG website.

Access Tank Through Riser

Cruz, 1999; DOE/RL, 1999; Environmental Management, 1998c; Gephart and Lundgren, 1996; Khaleel, 1999; Tank Focus Area, 1998a,b.

Active Neutron

BNFL, 1998; Canberra, 1998; DOE/ORO, 1999; DOE/SRO, 1999; Department Standards Committee, 1999; Dua, 1999; Fortner, 1999; Gilpin, 1999; INEEL, 1999 b; Kapaun, 1999.

Analytical Laboratory: Non-radioactive

Cortes, 1995; Environmental Management, 1998e,f; Environmental Protection Agency, 1998e,f,g,h,i,j,k; INEEL, 1999b; Klatt, 1996; Koegler, 1999; Loaiciga et al. 1997; Michael, 1999.

Analytical Laboratory: Radioactive

DOE/RL, 1999; DOE/SRO, 1999; Environmental Management, 1998f,m; Fernald Environmental Management Project-STCG, 1999; INEEL, 1999b; Loaiciga et al. 1997; Koegler, 1999.

Calorimetry Technology

Antech, 1999; Bracken et al. 1998; DOE 1995; DOE/SRO, 1999; Encyclopaedia Britannica, 1999; Hsue et al. 1997.

Cold Vapor Atomic Absorption (AA) for Hg

Cole Parmer, 1999; Dean, 1995; DOE/ORO, 1999; Federal Remediation Technology Roundtable, 1999; Loaiciga et al. 1997; Solomon, 1999a.

Cone Penetrometer

Bratton, 1999; Cruz, 1999; Environmental Management, 1999a,c,k; Environmental Protection Agency, 1997b, 1998e; Federal Remediation Technology Roundtable, 1999; Tanks Focus Area, 1997; Wyatt et al. 1997.

Conservative Estimate

DOE/SRO, 1999; INEEL, 1999b.

Core and Other samples

DOE/SRO, 1999; Environmental Management, 1998i,j,n; INEEL, 1999 b.

Coupon Tests

Corrosion Testing Laboratories, 2000; DOE/SRO, 1999; FTI Anamet, 1999; Howell, 1997 and 1998; INEEL, 1999 b. 
Culture Methods

Agdia, 2000; California See \& Plant, 1999; Encyclopaedia Britannica, 1999; Fisher, 2000; Howell, 1998; INEEL, 1999b.

Destructive Sampling

Bio-Imaging, 1999a; DOE/CAO, 1996b; DOE/OH, 1999; DOE/ORO, 1999; DOE/SRO, 1999; Department Standards Committee, 1996; INEEL, 1999b; Oak Ridge National Laboratory, 1999; Waste Policy Institute, 1999.

Discrete Sampling of Process Water in Pipes

Cruz, 1999; DOE/SRO, 1999.

Drilling: Cable Tool

Cruz, 1999; DOE, 1995; Environmental Management, 1999a, c; Federal Remediation Technology Roundtable, 1999; Loaiciga et al. 1997; Masten and Booth, 1996; Pacific Northwest National Laboratory, 1998 and 1999a; Smalley, 1999; Tanks Focus Area, 1997; Thornton, 1999.

Drilling: Hollow Auger

Carmichael, 1989; Environmental Management, 1999b,k; Enviromental Protection Agency, 1998a; Federal Remediation Technology Roundtable, 1999; Loaiciga et al. 1997; Mitchem, 1999; Pitkin et al. 1999; Smuin, 1995.

Drilling Methods for Tanks

CMST,1998; DOE/RL, 1999; Gephart and Lundgren, 1996; Pacific Northwest National Laboratory, 1998; Smalley, 1999; Stang, 1997; Tanks Focus Area, 1997.

Drilling: Rotary

DOE, 1995; Federal Remediation Technology Roundtable, 1999; Loaiciga et al. 1997; Masten and Booth, 1996.

Drilling: Sonic

Armstrong et al. 1998; DOE/RL, 1995; Environmental Management, 1995; GeoDrilling International, 1998; Loaiciga et al. 1997; Tyler et al. 1999.

Drive Point

Federal Remediation Technology Roundtable, 1999; Geoprobe, 1999; Loaiciga et al. 1997; Sherbert, 1999.

Drum Headspace Sampling

Barile, 1998; Collins et al. 1998; Defense Nuclear Facilities Safety Board, 1997; DOE/CAO, 1996a,b; INEEL, 1999b.

Ductile-Brittle Temperature Charts

INEEL, 1999b.

Eddy Current Techniques

Anderson et al. 1995; Birring, 1999; DOE/RL, 1999; EPD, 2000; INEEL, 1999a; Thomas, 1995.

Electrical Resistivity

Bergstrom and Mitchell, 1996a; Child, 1997; DOE/ORO, 1999; Environmental Management, 1998k; Enviromental Protection Agency, 1995; EPA Reachit, 1999; Geometrics, 1999; Geosphere, 1997; Geoterrex, 1999; Jerimov, 1999; K.D. Jones, 1999; Loaiciga et al. 1997; 
MGC, 1999; Mitcham, 1999; National Technology Transfer Center, 1999; Schwendeman and Wilcox, 1989; Sharma, 1997; Smith, 1999.

Electromagnetic Surveys

Bergstrom, 1996b; Environmental Management, 1998k; Environmental Protection Agency, 1997b; Gisco, 2000; Hopmans et al. 1999; Instrument Depot, 2000; Schonstedt, 2000; Sharma, 1997.

\section{Excavation of Test Trenches or Pits}

Bechtel, 1996; Boggs and Shaddoan, 1996; Environmental Management, 1998c,g and 1999e; Federal Remediation Technology Roundtable, 1999; Fernald Environmental Management Project-STCG, 1999; Loaiciga et al. 1997; Masten and Booth, 1996; Pacific Northwest National Laboratory, 1998; Tanks Focus Area, 1997; Thompson Machinery, 1999.

Gamma Spectroscopy

Biodex, 1999; Canberra, 1998; Department Standards Committee, 1999; DOE/CAO, 1996b; DOE/ORO, 1999; DOE/SRO, 1999; Dua, 1999; Environmental Management, 1998i and 1999f; Environmental Protection Agency, 1997b; Fortner, 1999; Gilpin, 1999; INEEL, 1999b; Kapaun, 1999; Lockheed, 1998; Oak Ridge National Laboratory, 1999; Pacific Northwest National Laboratory, 1999; Studiecentrum voor Kernenergie - Centre d'étude de l'Energie Nucléaire, 1999; Westinghouse Savannah River Corporation, 1999.

\section{Geophysical Logging}

Berwick et al, 1998; DOE/GJO, 1998; Keck, 1997; Loaiciga et al 1997; Mitcham, 1999; Mount Sopris, 1997; Pacific Northwest National Laboratory, 1998; Sharma, 1997.

Grab Sampling ("Bottle-on-a-String")

CMST-CP, 1999; Cruz, 1999; DOE, 1993; DOE/SRO, 1999; Environmental Management, 1999g; Fluor Daniel Hanford, 1998; Gephart and Lundgren, 1996; Maraj, 1997.

\section{Gravity Survey}

Edcon, 1999; LaCoste \& Romberg, 1999; Microgeophysics Corporation, 1999; Scintrex, 1999a,b; Sharma, 1997; Shoppach, 1999; Technos, 1999.

\section{Ground Penetrating Radar}

Bergstrom and Mitchell, 1996a; Child, 1997; DOE/RL, 1999; DOE/SRO, 1999; EPA Reachit, 1999; Federal Remediation Technology Remediation, 1999; Geometrics, 1999; Gisco, 1998; Hunaidi and Giamou, 1998; K.D. Jones, 1999; Lee, 1999; Loaiciga et al, 1997; Lyle, 1998; Koppenjan et al. 1998; Microgeophysics Corporation, 1999; Mitcham, 1999; Pacific Northwest National Laboratory, 1998; SENSOFT, 1999a,b; Sharma, 1997; Smith, 1999; Wyatt et al. 1997.

Groundwater Monitoring/Cased Well

Carmichael, 1989; Cruz, 1999; DOE/RL, 1999; DOE/SRO, 1999; Environmental Management, 1998k,1; Environmental Protection Agency, 1995; Federal Remediation Technology Roundtable, 1999; Freeze and Cherry, 1979; Instrument Northwest, 1993; Loaiciga et al. 1997; Schwendeman and Wilcox, 1989; Smuin, 1995; Tanks Focus Area, 1997.

Inductively Coupled Plasma - Mass Spectroscopy (ICP/ICP-MS)

Federal Remediation Technology Roundtable, 1999; Loaiciga et al. 1997; Solomon, 1999a.

$\underline{\text { Inner Capsule Movement Test (ICMT) }}$

DOE/RL, 1996 and 1999 
Intrusively Enter Pipes

DOE/SRO, 1999

Liquid Penetrant Testing

Godfrey, 1999; INEEL, 1999b; Magnaflux, 1998; Non Destructive Testing Association, 1996.

Loss on Ignition (LOI)

DOE/SRO, 1999; Fisher, 2000; Haschke and Ricketts, 1995; Hsue et al. 1997; Inert Systems, 2000; Los Alamos National Laboratory, 1997; Martinez et al. 1998.

Magnetic Anomaly Detection

Environmental Management, 1998k; Enviromental Protection Agency, 1997b; Loaiciga et al. 1997; Schonstedt, 2000; Sharma, 1997; Surveyors Shop, 2000.

Material Balance Calculations/Measurements

CMST-CP, 1998; Gephart and Lundgren, 1996; Schwendeman and Wilcox, 1989; Westinghouse Hanford Corporation, 1995.

Noble Gas and Tracer Experimentation

DOE/ORO, 1999; Environmental Management, 1998k; LeCain, 1998; Oklahoma University, 1997; Pennsylvania Department of Environmental Protection, 1997; Quinlan, 1990; Webster, 1996; Technos, 1999.

Optical Sludge/Supernate Interface Detector

DOE/SRO, 1999; Hylton et al. 1995; Markland, 1999; Speed, 1994; Tansony, 2000.

Passive Neutron

BNFL, 1998; Canberra, 1998; DOE/ORO, 1999; Department Standards Committee, 1999; Dua, 1999; Fortner, 1999; Gilpin, 1999; INEEL, 1999b; Lockheed, 1998; Kapaun, 1999; Studiecentrum voor Kernenergie - Centre d'étude de l'Energie Nucléaire, 1999.

PCB Test Kits

Cortes, 1995; Dexsil, 1999; Environmental Protection Agency, 1998f,g,h,i,j,k; Loaiciga et al. 1997; Millipore, 1995; National Technology Transfer Corporation, 1999; Silliman, 1999.

Periodic Trial Burns and Feed Analysis

DOE/SRO, 1999; INEEL, 1999b; Washington Administrative Code, 1999.

Portable Field Gas Chromatograph (GC)

Cole Parmer, 1999; DOE/ORO, 1999; Environmental Protection Agency, 1997a,b,c; EPA Reachit, 1999; Environmental Rental. 1999; Loaiciga et al. 1997; National Technology Transfer Corporation, 1999.

Portable Hg Vapor Analyzer

Arizona Instruments Corporation, 1999; Band, 1999; Cole Parmer, 1999; DOE/ORO, 1999; Environmental Rental. 1999; Fisher, 1998; Kirk, 1999; SRI, 1999.

Process Knowledge

DOE/ORO, 1999; DOE/RL, 1999. 


\section{Radiation Survey by Technician}

Biodex, 1999; Brehm, 1998a; CMST-CP, 1999; Davis, 1996; DOE/ORO, 1999; Environmental Management, 1998a,b,c,d,g and 1999d; Fernald Environmental Management Project-STCG, 1999; Koegler, 1999; Wade, 1997.

$\underline{\text { Radiography }}$

Anderson et al. 1995; Bio-Imaging Research, 1999; DI Scan, 1998; DOE/CAO, 1996a,b; Department Standards Committee, 1999; Environmental Management, 1998a; Faxitron, 1999; Gilpin, 1999; INEEL, 1999b; Martz et al. 1994; Oak Ridge National Laboratory, 1999; Rotella, 1999; Waste Policy Institute, 1999.

Remote Roving Vehicles to Measure Gamma Ray Emissions

Bauer, 1996; Campbell Scientific, 2000; DOE/SRO, 1999; Environmental Management, 1998c; Federal Energy Technology Center, 1999; Gisco, 2000; Josten and Gehrke, 1998; Kidd Karts, 2000; Nuclear Research Corporation, 1999; Skelter Imports, 1999; Yahoo, 2000.

\section{Sample Waste During Transport}

INEEL, $1999 b$.

$\underline{\text { Seismic Refraction }}$

Child, 1997; DOE/ORO, 1999; Environmental Management, 1998k; Environmental Protection Agency, 1997b; EPA Reachit, 1999; Federal Remediation Technology Roundtable, 1999; Geometrics, 1999; Geosphere, 1997; Hager, 1999; Microgeophysics Corporation, 1999; Mitcham, 1999; Schwendeman and Wilcox, 1989; Scintrex, 1999a,b; Sharma, 1997; Smith, 1999.

\section{$\underline{\text { Sonic Methods }}$}

Alberta Locators, 1999; American Water Works Association, 1987; DOE/ORO, 1999; Dixie, 1999; Eckert, 1992; Goldak, 1998; Hunaidi et al. 1999; Keeling, 1999; Pollard, 1999; Roach, 1988.

\section{$\underline{\text { Split Spoon Sampler }}$}

Environmental Protection Agency, 1998a; Pacific Northwest National Laboratory, 1999c.

Swipe Analysis for PCB

Environmental Protection Agency, 1999; INEEL, 1999 b.

Thermal Emission Spectroscopy

Cole Parmer, 1999; EPD, 2000; Soloman, 1999b.

Ultrasonic Techniques

Anderson et al. 1995; Birring, 1999; Bush et al. 1995; Corvib, 2000; DOE/RL, 1999; EPD, 2000; Garcia and Porter, 1995; Geneq, 2000; Microphotonics, 2000; Thomas, 1995.

Vacuum Level Test

INEEL, 1999b.

Video Inspection (D\&D)

DOE/RL, 1998; Environmental Management, 1998c,h; INEEL, 1999b; Koegler, 1999; Pacific Northwest National Laboratory, 1998. 
Video Inspection (Tanks)

DOE/RL, 1998a and 1999; Environmental Management, 1998c; Gephart and Lundgren, 1996; Koegler, 1999; Pacific Northwest National Laboratory, 1998; Westinghouse Hanford Corporation, 1995.

Visual Examination of SNF

EM, 1999f; INEEL, 1999b.

Volume Survey of Lead Brick

Environmental Management, 1998j; INEEL, 1998 and 1999a,b.

Wooden Dowel Method

DOE/RL, 1999; Koegler, 1999.

X-ray Fluorescence (XRF)

Environmental Management, 1998e; Environmental Protection Agency, 1998b,c,d; Environmental Rental. 1999; Federal Remediation Technology Roundtable, 1999; National Technology Transfer Corporation, 1999; Sackett, 1996; Solomon, 1999a.

\subsection{REFERENCES BY AUTHOR}

Agdia, 2000, "Price List and Policies," Agdia, Inc., Elkhart, Indiana, <http://www.agdia.com/ testing/prices.html>

Alberta Locators, Inc., July 22, 1999 (last updated), homepage, <http://www.leaklocate.com/>, Calgary, Alberta.

American Water Works Association, 1987, Leaks in Water Distribution Systems A Technical/Economic Overview, Denver, Colorado.

Anderson, M.T., D.C. Kunerth, J.R. Davidson, August 1995, Nondestructive Examination Technologies for Inspection of Radioactive Waste Storage Tanks, Idaho National Engineering Laboratory, Materials Physics Department, Idaho Falls, Idaho.

ANTECH Corporation, December 17, 1999, "Transportable Plutonium Assay Calorimeter Series 200," Antech Corporation, Westminster, Colorado, <http://www.antech-inc.com/ technotes/technote $3 . h t m l>$.

Arizona Instruments Corporation, July 20, 1999 (last updated), “Jerome 431-X Mercury Vapor Analyzer" web page <http://www.azic.com/product/jer431x.html>, Phoenix, Arizona.

Armstrong, Aran, Wayne Pierre, E. Jean Underwood, Kathleen Falconer, and David Wilkins, December 1998, "Remote Subsurface Exploration into a Radioactive and Hazardous Waste Pit," Techno Ventions '98, Orlando, Florida.

Band, Mark, June 10, 1999, fax including letter and company literature, Arizona Instruments Corporation, Phoenix, Arizona.

Barile, Suzy, October 26, 1998, "Raleigh firm digs into feds' nuclear waste disposal plan," The Business Journal, < http://www.amcity.com/triangle/stories/1998/10/26/focus3.html.>

Bauer, R.G., September 24, 1996, Radioactive Contamination Mapping System Detailed Design Report, BHI-00619, Rev. 0, Bechtel Hanford Inc., Richland, Washington. 
Bechtel Hanford, Inc., 1996, Engineering Evaluation/Cost Analysis for 100-N Area Waste, BHI00785, Rev. 0, Richland, Washington.

Bergstrom, K.A., Mitchell, T.H., May 1996a, Geophysical Investigations of the 116-C-5 Retention Basin 100-BC-1, Operable Unit, BHI-00716, Rev. 0, Prepared for the DOE, Office of Environmental Restoration and Waste Management by Bechtel Hanford, Inc., Richland, Washington.

Bergstrom, K.A., August 5, 1996b, Geophysical Investigation of the 116-H Liquid Waste Disposal Trench, 100-HR-1 Operable Unit, BHI-00715, Rev. 0, Bechtel Hanford Incorporation, Richland, Washington.

Berwick, Joel D., Brodeur, John, Butherus, Michael C., Bertsch, James F. 1998, (no date given, document obtained at TechnoVentions98, Lake Buena Vista, Florida, December 9-12, 1998), "Application of Nuclear Logging Technology," DOE-GJO and MACTEC Environmental Restoration Services, Colorado.

Biodex Medical Systems, 1999, Radiation Safety, Supplies and Accessories, Catalog \#13, Shirley, New York.

Bio-Imaging Research, Inc., February 19, 1999 (last updated), "WIT System: Benefits and Features," web page <http://www.bio-imaging.com/pages/wit.htm>, Lincolnshire, Illinois.

Birring, Anmol S., June 1999, "Selection of NDT Techniques for Inspection of Heat Exchanger Tubing," presentated at the ASNT's International Conference on Petroleum Industry Inspection Conference, Houston, Texas, http://www.ndeassociates.com/asnt99.htm.

BNFL Instruments, Inc., 1998, Instrument Products Literature, Los Alamos, New Mexico.

Boggs, C.J., Shaddoan, W.T., 1996, "Cost Savings Associated with Landfilling Wastes Containing Very Low Levels of Uranium," CONF-960110-3, ANL/EA/CP-88217, Argonne National Laboratory, presented at mid-year topical meeting of the Health Physics Society.

Bracken, D.S., R. Biddle, and C. Rudy, 1998, Performance Evaluation of a Commercially Available Heat Flow Calorimeter and Applicability Assessment for Safeguarding Special Nuclear Materials, LA-UR-98-3090, Los Alamos National Laboratory, New Mexico, presented at the Institute of Nuclear Materials Management $39^{\text {th }}$ Annual Meeting, Naples, Florida, July 26-30, 1998.

Bratton, Wes, March 1999, email from Wes Bratton to Joe Cruz, forwarded to me by Joe Cruz, Richland, Washington.

Brehm, D.M., March 1998, Technical Basis to Describe the Use of the Eberline E-600, BHI01054, Rev. 2, Prepared for the DOE, Office of Environmental Restoration by Bechtel Hanford, Inc., Richland, Washington.

Bush, S., K. Bandyopadhyay, M. Kassir, B. Mather, P. Shewmon, M. Streicher, B. Thompson, D. van Rooyen, and J. Weeks, 1995, Nondestructive Examination of DOE High-Level Waste Storage Tanks, BNL-61647, Brookhaven National Laboratory.

California Seed and Plant, April 3, 1999, Price list, Elverta, California, $<$ http://www.calspl.com/Price\%201ist.htm>. 
Campbell Scientific, Inc. 2000, Price list of products from company, Logan, Utah.

Canberra Industries, Inc., 1998, Nuclear Products Group, Instrument Products Literature, Meriden, CT.

Carmichael, John K., 1989, An Investigation of Shallow Ground-Water Quality Near East Fork Poplar Creek, Oak Ridge, Tennessee, Water-Resources Investigations Report 88-4219, U.S. Geological Survey, Nashville, Tennessee.

CMST-CP, August 1998, Technology Summary Fiscal Year 1998, Department of Energy, Office of Environmental Management, Office of Science and Technology, Characterization Monitoring and Sensor Technology - Crosscutting Program, Washington, D.C.

CMST-CP, March 8-11, 1999, CMST-CP Fiscal Year 1999 Annual Review Meeting, Gaithersburg, Maryland.

Cole Parmer, 1999, "Cole-Parmer's Industrial Advantage" (Catalog), Cole-Parmer Instrument Company, Vernon Hills, Illinois.

Collins, Susan L., Henry T. Sessions, and Kenneth E.Cheeks, 1998, TRU Drum Headspace Gas Analysis System, WSRC-MS-98-00705,< http://www.srs.gov/general/scitech/fulltext/ms9800705/ms9800705.html $>$.

Corrosion Testing Laboratories, February 13, 2000, "Corrosion Testing Price List," Corrosion Testing Laboratories, Inc., Newark, Delaware, $<$ http://www.corrosionlab.com/corprice.html $>$.

Cortes, Don, June 29, 1995, Immunoassay vs. Mobile Laboratory, PCB Testing, Draft Memorandum, Monroe County Net Incorporated, $<$ http://www.mcni.net/ copa/testkit.htm>.

Corvib, February 8, 2000, "Dakota MX Series," Weston, Ontario $<\mathrm{http}: / /$ www.corvib.com/dakota/dx-1.htm>.

Cruz, Joe, March 1999, SAIC, Richland, Washington.

Davis, A.I., 1996, Instrumental Basis Utilizing a Sodium Iodide Detector for Radioactive Soil Evaluations for Site Remediation, BHI-00885, Rev. 0, Prepared for the Department of Energy, Office of Environmental Restoration by Bechtel Hanford, Inc., Richland, Washington.

Dean, John A., 1995, Analytical Chemistry Handbook, McGraw-Hill, New York.

Defense Nuclear Facilities Safety Board (DNFSB), March 14, 1997, Memorandum for G.W. Cunningham from J. Kent Fortenberry and Joe Sanders, $<$ http://www.dnfsb.gov/weekly/sr/1997/sr031497.htm>.

Department Standards Committee, August 7, 1996, UCRL-AR-122882, Appendix F - Standards Listing with Expanded Descriptions, <http://tis.eh.doe.gov/dsc/llnl-apf.html $>$, Department of Energy, Environmental Safety and Health, Department Standards Committee, Technical Information Services, Washington, D.C.

Dexsil Corporation, 1999, "L2000 PCB/Chloride Analyzer," web page, <http:// www.dexsil.com/12000web.htm>, Hamden, Connecticut. 
DI Scan, January 14, 1998, "Pending arrival of digital detectors prompts debate over economics," <http://www.discan.com/features/xray.html>, Miller Freeman, Inc., San Francisco, California.

Dixie Metal Detectors, February 17, 1999 (last updated), "XLT-16 Liquid and Gas Leak Detector," <http://www.apex-ephemera.com/ treasure/ dixie/ security/ fisherxlt20.htm>, Jackson, Mississippi.

Department of Energy (DOE), August 10,1993, EA-0881; Environmental Assessment and (FONSI) Tank 241-c-103 Organic Vapor and Liquid Characterization and Supporting Activities, Hanford Site, Richland, Washington, DOE/EA-088, DOE, Washington, D.C., $<$ http://nepa.eh.doe.gov/ea/ ea0881/ea0881_1.html>.

DOE, 1995, Increasing Fissile Inventory Assurance Within the U.S. Department of Energy,

Department of Energy, Washington, D.C.,

$<$ http://tis.eh.doe.gov/oversight/reviews/fiss_rep.html $>$.

DOE/Carlsbad Area Office (CAO), April 1996a, Transuranic Waste Characterization Sampling and Analysis Methods Manual, Revision 1.0, DOE/WIPP-91-043, Carlsbad, New Mexico.

DOE/CAO, April 1996b, Mobile Systems Capability Plan, DOE/WIPP-96-1202043, Carlsbad, New Mexico.

DOE-Grand Junction Office (GJO), 1998 (no date given, document obtained at TechnoVentions98, Lake Buena Vista, Florida, December 9-12, 1998), "Elements of Successful and Highly Cost-Effective In Situ Characterization,” Department of Energy Grand Junction Office, Grand Junction, Colorado.

DOE/Oak Ridge Office (ORO), 1999, "Technology Needs Database," http://www.em.doe.gov/techneed/, Department of Energy, Office of Environmental Management, Oak Ridge Office, Oak Ridge, Tennessee.

DOE/Ohio (OH), 1999, “Technology Needs," <http://www.ohio.doe.gov/oh-stcg/needs.asp>, Department of Energy, Ohio Field Office, Fernald, Ohio.

DOE/Richland (RL), 1995, "Hanford Pollution Prevention Success Stories, Well Drilling", Hanford web page, Richland, Washington, $<$ http://www.hanford.gov/polprev/fy95/43.htm>.

DOE/RL, August 1996, Tank Waste Remediation System, Hanford Site, Richland, Washington, Final Environmental Impact Statement, Volume 2, DOE/EIS-0819, U.S. Department of Energy and Washington State Department of Ecology, Hanford, Washington.

DOE/RL, June 3, 1998, "Estimate Revised for Waste Volume in Tank AX-104," $<$ http://www.hanford.gov/tanks/hti/>, Department of Energy - Richland Office.

DOE/RL, 1999, "Site Technology Needs," web page <http://www.pnl.gov/ stcg/needs.stm>, Department of Energy, Richland Office, Richland, Washington.

DOE/Savannah River Office (SRO), 1999, "Needs Statements," Department of Energy, Savannah River Operations Office, Savannah River Office, South Carolina, $<$ http://www.srs.gov/general/srtech/stcg/needstmt.htm>. 
Dua, S.K., 1999, personal communications, Florida International University - Hemispheric Center for Environmental Technology, Miami, Florida.

Eckert, Eric G., 1992, Acoustic location of leaks in pressurized underground petroleum pipelines, Risk Reduction Engineering Laboratory, Office of Research and Development, EPA, Cincinnati, Ohio.

EDCON, January 28, 1999 (last updated), "Gravity and Magnetic Services," web page $<$ http://www.edcon.com/services.htm $>$, Denver, Colorado.

Encyclopaedia Britannica, 1999, <http://www.britannica.com>.

Environmental Management, DOE, April 1995, ResonantSonic ${ }^{S M}$ Drilling Innovative Technology Summary Report

Environmental Management, DOE, February 1998a, Innovative Technology Summary Report, GammaCam $^{T M}$ Radiation Imaging System, DOE/EM-0345, Washington, D.C.

Environmental Management, DOE, February 1998b, Innovative Technology Summary Report, Gamma-Ray Imaging System, DOE/EM-0390, Washington, D.C.

Environmental Management, DOE, December 1998c, Innovative Technology Summary Report, Dual Arm Work Platform Teleoperated Robotics System, DOE/EM-0389, Washington, D.C.

Environmental Management, DOE, April 1998d, Innovative Technology Summary Report, Mobile Automated Characterization System (Draft), Washington, D.C.

Environmental Management, DOE, April 1998e, Innovative Technology Summary Report, Portable X-Ray Fluorescence Spectrometer (Draft), DOE/EM-X, Washington, D.C.

Environmental Management, DOE, April 1998f, Innovative Technology Summary Report, Road Transportable Analytical Laboratory, DOE/EM-0381, Washington, D.C.

Environmental Management, DOE, February 1998g, Innovative Technology Summary Report, Pipe Crawler ${ }^{\circledR}$ Internal Piping Characterization System, DOE/EM-0355, Washington, D.C.

Environmental Management, DOE, January 1998h, "Dual Arm Work Platform Teleoperated Robotics System (DRAFT)," DOE/EM-XXXX, Prepared for the DOE, EM, Office of Science and Technology.

Environmental Management, DOE, January 1998i, "In-Situ Object Counting System (ISOCS),"Washington, D.C.

Environmental Management, DOE, 1998j, "Environmental Waste Issues: Lessons Learned," Washington, D.C., <http://www.em.doe.gov/tie/sess6.html $>$.

Environmental Management, DOE, April 4, 1998k, "About Definition of Environmental Restoration Program Requirements,"

$<$ http://www2.em.doe.gov/define/techs/chap2.html $>$.

Environmental Management, DOE, December 19981, Innovative Technology Summary Report, Direct Sampling Ion Trap Mass Spectrometry (DSITMS), Washington, D.C. 
Environmental Management, DOE, December, 1998m, Innovative Technology Summary Report, BetaScint ${ }^{T M}$ Fiber-Optic Sensor for Detecting Strontium-90 and Uranium-238 in Soil, Washington D.C.

Environmental Management, DOE, January, 1998n, Innovative Technology Summary Report, Portable X-Ray Fluorescence Spectrometer (Draft), Washington, D.C.

Environmental Management, 1999a, home page, <http://www.em.doe.gov/>, Department of Energy, Office of Environmental Management, Washington, D.C.

Environmental Management, DOE, September 1999b, Innovative Technology Summary Report, Remote Underwater Characterization System (RUCS), DOE/EM-0457, Washington, D.C.

Environmental Management, DOE, July 1999c, Innovative Technology Summary Report, Raman Probe, DOE/EM-0442, Washington, D.C.

Environmental Management, DOE, May 1999d, Innovative Technology Summary Report, Corrosion Probe, DOE/EM-0430, Washington, D.C.

Environmental Management, DOE, April 23, 1999e, "Range of Disposal Costs for DOE and Commercial Sites", DOE, Office of Environmental Management, $<\mathrm{http}$ ://www2.em.doe.gov/llw/range.html $>$.

Environmental Management, September 1999f, Innovative Technology Summary Report: Nondestructive Waste Assay Using Gamma-Ray Active \& Passive Computer Tomography, DOE/EM-0470, Washington, D.C.

Environmental Management, DOE, September 1999g, Innovative Technology Summary Report, Fluidic Sampler, DOE/EM-0485, Washington, D.C.

Environmental Protection Agency, June 26, 1995, Technical Background Document, Cost Analysis for the Proposed Rule on Alternatives for Ground-Water Monitoring at Small, Dry or Remote Municipal Solid Waste Landfills (Draft), <http://www.epa.gov/epaoswer/ non-hw/muncpl/gwm.htm>, Washington, D.C.

Environmental Protection Agency, December1997a, Environmental Technology Verification Report, Field Portable Gas Chromatograph/Mass Spectrometer, Bruker-Franzen Analytical Systems, Inc. EM640 ${ }^{T M}$, EPA/600/R-97/149, Washington, D.C.

Environmental Protection Agency, November1997b, Field Analytical and Site Characterization Technologies Summary of Applications, EPA-542-R-97-011, Washington, D.C.

Environmental Protection Agency, December 1997c, Environmental Technology Verification Report, Field Portable Gas Chromatograph/Mass Spectrometer, Viking Instrument Corporation SpectraTrak ${ }^{T M}$ 672, Washington, D.C.

Environmental Protection Agency, August 1998a, Environmental Technology Verification Report, Soil Sampling Technology, Simulprobe Technologies, Inc. Core Barrel Sampler, Washington, D.C.

Environmental Protection Agency, August 1998b, Environmental Technology Verification Report, Field Portable X-ray Fluorescence Analyzer, Spectrace TN 9000 and TN Pb Field Portable X-ray Fluorescence Analyzers, Washington, D.C. 
Environmental Protection Agency, August 1998c, Environmental Technology Verification Report, Field Portable X-ray Fluorescence Analyzer, HNU Systems SEFA-P, EPA/600/R-97/144, Washington, D.C.

Environmental Protection Agency, August 1998d, Environmental Technology Verification Report, Field Portable X-ray Fluorescence Analyzer, Metorex X-Met 920-P and 940, EPA/600/R-97/146, Washington, D.C.

Environmental Protection Agency, September 1998e, Innovations in Site Characterization Case Study: Hanscom Air Force Base, Operable Unit 1 (Sites 1,2, and 3), EPA-542-R-98-006, Washington, D.C.

Environmental Protection Agency, August 1998f, Environmental Technology Verification Report, Immunoassay Kit, Strategic Diagnostics Inc. RAPID Assay System for PCB Analysis, EPA/600/R-98/111, Washington, D.C.

Environmental Protection Agency, August 1998g, Environmental Technology Verification Report, Immunoassay Kit, Hach Company PCB Immunoassay Kit, EPA/600/R-98/110, Washington, D.C.

Environmental Protection Agency, December 1998h, Environmental Technology Verification Report, Immunoassay Kit, EnviroLogix, Inc., PCB in Soil Tube Assay, EPA/600/R98/173, Washington, D.C.

Environmental Protection Agency, August 1998i, Environmental Technology Verification Report, Immunoassay Kit, Strategic Diagnostics, Inc. EnviroGard PCB Test Kit, EPA/600/R-98/113, Washington, D.C.

Environmental Protection Agency, August 1998j, Environmental Technology Verification Report, Immunoassay Kit, Strategic Diagnostics, Inc., D TECH PCB Test Kit, EPA/600/R-98/112, Washington, D.C.

Environmental Protection Agency, August 1998k, Environmental Technology Verification Report, Immunoassay Kit, Electrochemical Technique/Ion Specific Electrode, Dexsil Corporation L2000 PCB/Chloride Analyzer, EPA/600/R-98/111, Washington, D.C.

Environmental Protection Agency, May 1999, Innovations in Site Characterization Case Study: Dexsil L2000 PCB/Chloride Analyzer for Drum Surfaces, EPA-542-R-99-003, EPA, Office of Solid Waste and Emergency Response, Washington, D.C.

Environmental Rental, 1999, "Environmental Rental quality instrument rental, sales and repair," home page $<$ http://environmentalrental.com/>, Grand Rapids, Michigan.

EPA Reach It, 1999, "Characterization Technology Overview," <http:/www.epareachit.org/ DetailCharacterization/Overview.asp>, Environmental Protection Agency, Washington, D.C.

EPD Technology Corporation, February 25, 2000, "Instruments for Industry," Elmsford, New York <http://epdtech.com/prdcts.htm>.

Faxitron X-Ray Corporation, June 17, 1999, “Torrex Cabinet X-Ray Systems,” <http:// www.faxitron.com/p1.htm>, Wheeling, Illinois. 
Federal Energy Technology Center (FETC), 1999, "Technical Demonstration Summary Sheet, Global Positioning Radiometric Scanner System (GPRS)", INEEL, $<$ http://techcatalog.inel.gov/documents/teb/global_positioning_radiometric_scanner/gprs _lsddp_fs.pdf. $>$.

Federal Remediation Technologies Roundtable, 1999, "Field Sampling and Analysis

Technologies Matrix Version 1.0, Table of Contents,"

$<$ http://www.frtr.gov/site/toc.html $>$, Washington, D.C.

Fernald Environmental Management Project (FEMP), Site Technology Coordination Group, June 15, 1999 (last updated), "Fernald Technical Needs," <http://www.fernald.gov/ technology\%20programs/stcg/technolo.htm>.

Fisher Scientific, 1998, Fisher Catalog 98/99, Pittsburgh, Pennsylvania.

Fisher Scientific, 2000, On-line Catalog, <http://www3.fishersci.com/catalogs $>$.

Fluor Daniel Hanford, Inc., Technology Management, 1998, Nested Fixed Depth Fluidic Sampler, TM-DEM-98-004, <http://www.hanford.gov/techmgmt/factsheets/demos/ 1998/depthsam.html>, Richland, Washington.

Fortner, Bob, March 12, 1999, e-mail, Canberra Industries, Meriden, Connecticut.

Freeze, R. Allan, Cherry, John A., 1979, Groundwater, Prentice-Hall, Inc., Englewood Cliffs, New Jersey.

FTI Anamet, August 18, 1999, "Schedule of Rates and Charges," FTI Anamet, Hayward, California, <http://www.ftianamet.com/rates.html>.

Garcia, Karen M., and Allen M. Porter, February 1995, Remote Measurement of Corrosion Using Ultrasonic Techniques INEL-94/0162, Idaho National Engineering Laboratory, Lockheed Idaho Technologies Company, Idaho Falls, Idaho.

Geneq, Inc., February 28, 2000, "Datalogging Ultrasonic Thickness Gauge," Montreal, Quebec, $<$ http://www.geneq.com/catalog/en/dutg.htm $>$.

Geodrilling International, February 1998, "Sonic Drilling: An Environmental Imperative?" The Mining Journal Ltd., Vol. 6, No. 1, <http://www.miningjournal.com/mj/GEODRILL/gdi0298.htm>.

Geometrics, June 15, 1999 (last updated), web page "Geometrics Instrumental Rentals," $<\mathrm{http}$ ://www.geometrics.com/lease_rentals.html $>$, San Jose, California.

Geoprobe Systems, May 27, 1999 (last updated), "What is a Geoprobe?", $<$ http://www.geoprobesystems.com/whatisge.htm>, Salinas, Kansas.

Geosphere, Inc., November 11, 1997, "Look to Geosphere for Innovative Geophysical Solutions to Near-Surface Geological Problems," <http://www.geosphere.com>, Midland, Michigan.

Geoterrex-Dighem, April 16, 1999 (last updated), "Electrical Methods," web page $<$ http://www.geoterrex-dighem.com/ground/electric.html $>$, Ottawa, Ontario.

Gephart, R.E., Lundgren, R.E., 1996, Hanford Tank Clean up: A Guide to Understanding the Technical Issues, PNL-10773, Pacific Northwest Laboratory, Richland, Washington. 
Gilpin, Jeff, June 14, 1999, e-mail, Site Technology Coordination Group member at Oak Ridge, Tennessee.

Gisco, June 23, 1998, "Ground Penetrating Radar," web page <http://www.giscogeo.com/ pages/giscogpr.html>, Gisco ${ }^{\mathrm{TM}}$ Geophysical Instruments and Supply Company, Minneapolis, Minnesota.

Gisco, June 5, 2000, Internet Home page, Gisco ${ }^{\mathrm{TM}}$ Geophysical Instrument and Supply Company, Minneapolis, Minnesota, <http://www.giscogeo.com/>.

Godfrey Hands Ltd., 1999, "Liquid Penetrant Testing," <http://www.handsltd.demon.co.uk/pen.htm>.

Goldak, June 23, 1998, "Water Leak Detector," <http://www.goldak.com/ST/list Leak.htm>, Glendale, California.

Greem. Verity, December 19, 2,000, Marketing Secretary at Antech, Ltd., United Kingdom.

Hager Geoscience, Inc., July 15, 1999 (last updated), "Seismic Refraction" web page $<$ http://www.hagergeoscience.com/refrac.html>, Waltham, Massachusetts.

Haschke, John M., and Thomas E. Ricketts, August 1995, Plutonium Dioxide Storage: Conditions for Preparation and Handling, LA-12999-MS, Los Alamos National Laboratory, New Mexico.

Hopmans, Jan W., Jan M. H. Hendrickx, and John S. Selker, 1999, "Emerging Measurement Techniques for Vadose Zone Characterization," Chapter 11 in Vadose Zone Hydrology, ed. Marc B. Parlange and Jan W. Hopmans, Oxford University Press, New York, New York.

Howell, J.P., March 9 to 14, 1997, "Corrosion Surveillance in Spent Fuel Storage Pools (U)", presented at Corrosion NACEXPO/97 Annual Conference and Exposition at New Orlenes, Louisiana.

Howell, James P., 1998, Corrosion Surveillance for Research Reactor Spent Nuclear Fuel in Wet Basin Storage, WSRC-MS-98-00702, Westinghouse Savannah River Company, Aiken, South Carolina.

Hsue, S. T., J. E. Stewart, T. E. Sampson, G. Butler, C. R. Rudy, P. M. Rinard, October 1997, Guide to Nondestructive Assay Standards: Preparation Criteria, Availability, and Practical Considerations, LA-13340-MS, Los Alamos National Laboratory, New Mexico.

Hunaidi, Osama, Giamou, Peter, 1998, “Ground-Penetrating Radar for Detection of Leaks in Buried Plastic Water Distribution Pipes," Seventh International Conference on GroundPenetrating Radar, Lawrence, Kansas, USA, May 17-30, 1998.

Hunaidi, Osama, Chu, Wing, Wang, Alex, Guan, Wei, 1999, "Leak Detection Methods for Plastic Water Distribution Pipes,” AWWA Research Technology Transfer Conference, Fort Lauderdale, Florida, February 8-19, 1999.

Hylton, T.D., R. L. Cummins, E. L. Youngblood, and J. J. Perona, October 1995, Sludge Mobilization with Submerged Nozzles in Horizontal Cylindrical Tanks, ORNL/TM-1303, Oak Ridge National Laboratory, Oak Ridge, Tennessee. 
Idaho National Engineering and Environmental Laboratory (INEEL), October 1998, "Large Scale Demonstration and Deployment Project D\&D Needs," $<$ http://id.inel.gov/lsddp/fieldld.htm $>$.

INEEL, 1999a, "Site Technology Coordination Group Solutions of the Future, Technology Selection Form," Idaho Falls, Idaho, <http://techcatalog.inel.gov/>.

INEEL, 1999b, "Site Technology Coordination Group Solutions of the Future, Technology Needs and Opportunities by Number and Title," Idaho Falls, Idaho, $<\mathrm{http}: / /$ stcgneeds.inel.gov/num_name.asp $>$.

Inert Systems, 2000, "Chemistry Glovebox," Inert Systems, 1lc, Modesto, California, $<$ http://www.inertsystems.com/is/chem01.asp $>$.

Instrument Depot, April 10, 2000, "Specialty Monitoring Equipment," Instrument Depot $<$ http://www.instrumentdepot.com/specialt.htm>.

Instrument Northwest, 1993, "Case History," National Environmental Journal, July/August 1993, page 48.

Jermihov, Nicholas, July 1, 1999, fax, Geophysical Geological Instrument and Supply Co., St. Louise Park, Minnesota.

Josten, Nicholas, and Robert Gehrke, 1998, "In Situ Radiation Mapping for Assessment of Distributed Radioactive Contamination."

Kapaun, Ronald, March 15, 1999, e-mail, BNFL Instruments, Knoxville, Tennessee.

K.D. Jones Instrument Corporation, July 15, 1999, web page "Equipment Rentals" at $<$ http://www.kdjonesinstruments.com/equipment.html $>$, Normange, Texas.

Keck Instruments, Inc., June 11, 1997, “GR Natural Gamma Ray Logging System, Exploration for Minerals and Subsurface Structures," <http://www.keckinc.com/nfgr.htm>, Williamston, Michigan.

Keeling, David A., May 25, 1999 (last updated), "New Techniques in Water Leak Detection," $<$ http://www.heathltd.com/techpaper.htm>, Health Consultants Limited, Houston, Texas.

Khaleel, Raz, March 23, 1999, e-mail to Pete Molton, posted on "Surface Infiltration Around the Hanford Tanks" discussion page, $<\mathrm{http}$ //web1.ead.anl.gov/Forum/

Thread.cfm?CFAPP $=13 \&$ Thread_ID $=190 \& m c=3>$.

Kidd Karts, 2000, "Kidd Karts," Havelock, North Carolina, <http://www.gocarts.com/speedster.htm>.

Kirk, Paula, June 1999, e-mail and voice mail, Site Technology Coordination Group Coordinator at Oak Ridge, Tennessee.

Klatt, Leon N., 1996, A Retrospective Study of the Chemical Analysis Cost for the Remediation of Lower East Fork Poplar Creek, Oak Ridge, Tennessee, ORNL/TM-13645, Oak Ridge National Laboratory, Tennessee.

Koegler, Kim, 1999, conversation between Kim Koegler and Joe Cruz, information provided by Joe Cruz. 
Koppenjan, Steven K., Allen, Curt M., Gardner, Duane, Wong, Howard R., May 1998, “A Lightweight Ground Penetrating Radar," Seventh International Conference on GroundPenetrating Radar at the University of Kansas, Lawrence, Kansas, May 27-30, 1998.

LaCost and Romberg, June 28, 1999 (last updated), "LaCoste \& Romberg LLC, The first name in gravity since 1939," <http://www.lacosteromberg.com/>, Austin, Texas.

LeCain, Gary D., 1998, Results from Air-Injection and Tracer Testing in the Upper Tiva Canyon, Bow Ridge Fault, and Upper Paintbrush Contact Alcoves of the Exploratory Studies Facility, August 1994 through July 1996, Yucca Mountain, Nevada, U.S. Geological Survey, prepared in cooperation with the Nevada Operations Office of DOE, WaterResources Investigation Report 98-4058, Denver, Colorado.

Lee, Richard, 1999, "The Role of Geophysics in the Characterization of Hazardous Waste Sites," $<$ http://www.kdjonesinstruments.com/paper1.html>, K.D. Jones Instrument Corporation, Normange, Texas.

Loaiciga, Hugo A. Renehan, Stephen, Weeks, Stephen, September 1, 1997, Survey of Current Practice of Environmental Characterization and Monitoring Techniques: Selected DOE Sites, Project Report, Bechtel Nevada, Las Vegas, Nevada.

Lockheed Martin Idaho Technologies Company, November 1998, Mixed Waste Focus Area/Characterization Monitoring Sensor Technology Nondestructive Waste Assay Capability Evaluation Project End-User Summary Report, INEEL/EXT-98-01108, Idaho Falls, Idaho.

Los Alamos National Labortory, March 1997, Materials Identification and Surveillance Project Item Evaluation, LA-13246-MS, Los Alamos, New Mexico.

Lyle Environmental Management, Inc., July 31, 1998, “Ground Penetrating Radar," $<$ http://www.lylelabs.com/gpr.htm>, Columbus, Ohio.

Magnaflux, June 25, 1998, "NDT Frequently Asked Questions," Magnaflux web page, Magnaflux, division of Illinois Tool Works, Inc., $<$ http://www.magnaflux.com/magnaflux/faqs.html $>$.

Maraj, Ramesh, September 30, 1997, "Preliminary Draft OST Cost Savings Analysis-FY97 Tanks Focus Area Review,” BDM International, Layton, Utah.

Markland Specialty Engineering, Ltd., 1999, "Manual Sludge Blanket Level Detection Markland Model 10 Sludge Gun ${ }^{\circledR}$, Toronto, Canada, $<$ http://www.sludgegun.com.

Martinez, Aaron M., William K. Hollis, James B. Rubin, Craig M. V. Taylor, Michael N. Jasperson, Donald E Vance, Joseph B. Rodriquez, 1998, "A Novel Analytical Methods for the Determination of Residual Moisture in Plutonium Dioxide: Supercritical Fluid Extraction/Fourier Transform Infrared Spectroscopy," $<$ http://searchpdf.adobe.com/proxies/2/17/66/58.html $>$.

Martz, Harry E., Schneberk, Daniel J., Roberson, G. Patrick, July 1994, Real-Time Radiography, Digital Radiography, and Computed Tomography for Nonintrusive Waste Drum Characterization, UCRL-JC-115670, Lawrence Livermore National Laboratory, Livermore, California. 
Masten, Dave, Booth, Steven R., March 1996, Cost Effectiveness of Sonic Drilling, Los Alamos National Laboratory, Los Alamos, New Mexico.

Microgeophysics Corporation, February 12, 1999, "MGC, Microgeophysics Corporation," $<$ http://www.microgeo.com/service/>, Wheat Ridge, Colorado.

Microphotonics, February 1, 2000, "Ultrasonic Thickness Gauge,"

$<$ http://www.microphotonics.com/sonogauge.html $>$.

Millipore, 1995, 1994-1995 Millipore Direct Catalog, "EnviroGard PCB Test Kit and Accessories," <http://www.bis.med.jhmi.edu/Dan/catal/milli/prd274.html>, web page of John Hopkins University Bioinformatics, Columbia, Maryland.

Mitcham Industries, Inc., 1999 (no date given), "Product Catalogue," $<$ http://www.mitchamindustries.com/mitcham/catalog.cfm $>$, Huntsville, Texas.

Mount Sopris Instruments, October 9, 1997, "MGX II Loggers,” <http://www.mountsopris.com/ prod01.htm>, Golden, Colorado.

National Technology Transfer Center, June 18, 1997, "Envirotrade Technology Summaries," $<$ http://www.nttc.edu/env/>, Wheeling, West Virginia.

Non Destructive Testing Association (NDTA), 1996, "NDT Methods: Liquid Penetrant Inspection," New Zealand, <http://www.winzurf.co.nz/ndta/ndtalp00.htm>.

Nuclear Research Corporation (NRC), January 18, 1999, " Nuclear Research Corporation introduces the latest and most versatile radiation monitoring technology available", $<$ http://www.nrc-ind.com/gard.html $>$.

Oak Ridge National Laboratory (ORNL), 1999, web page "Waste Examination and Assay Facility," <http://www.ornl.gov/armd/>, Oak Ridge National Laboratory, Oak Ridge, Tennessee.

Oklahoma University, March 11, 1997, “Oklahoma University National Science Foundation EPSCOR (Experimental Program to Stimulate Competitive Research) Project at the former Norman Landfill: Initiative for Automation and Characterization of an Environmental Research Field Site," <http://baked.ecn.ou.edu/ epscor/research.html>, Oklahoma University School of Civil Engineering and Environmental Science, Oklahoma.

Pacific Northwest National Laboratory (PNNL), 1998, "Webtech,” Pacific Northwest National Laboratory, Richland, Washington, <http://www.pnl.gov/WEBTECH/>.

Pennsylvania Department of Environmental Protection, 1997, "Chapter 3: Locations and Depths of Monitoring Wells," Groundwater Monitoring Guidance Manual, <http:// www.dep.state.pa.us/dep/deputate/watermgt/wsm/WSM_DWM/SrceProt/GrdMonitor/ch ap3.htm>, Pennsylvania.

Pitkin, Seth, Ingleton, Robert A., Cherry, John A., August 20, 1999 (last updated), "Use of a Drive Point Sampling Device for Detailed Characterization of a PCE Plume in a Sand Aquifer at a Dry Cleaning Facility," Solinst Canada Ltd., Georgetown, Ontario, $<$ http://solinst.com/Res/papers/TCE/TCE.html $>$. 
Pollard Underground Utility Products, September 1, 1999 (last updated), "Leak Detector," $<$ http://www.pollardwater.com/>, New Hyde Park, New York.

Quinlan, James F., 1990, "Special Problems of Ground-Water Monitoring in Karst Terrenes," Ground Water and Vadose Zone Monitoring, ASTM STP 1053, D.M. Nielsen and A.I. Johnson, Eds., American Society for Testing and Materials, Philadelphia, pp. 275-304.

Roach, Robert D., 1988, Evaluation of volumetric leak detection methods for underground fuel storage tanks, Environmental Protection Agency, Washington, D.C.

Rotella, Joe, July 23, 1999, fax, Tronix Inc., Stone Mountain, Georgia.

Sackett, Donald W., July 1, 1996, "Evaluation of a Field-Portable, X-Ray Fluorescence Analyzer for Department of Energy Application," <http://www.niton.com/doe_oak.html>, Niton Corporation, Bedford, Massachusetts.

Schonstedt, May 25, 2000, Internet Home page, Schonstedt Instrument Company, Kearneysville, West Virginia, <http://www.schonstedt.com/>.

Schwendeman, Todd G.; Wilcox, H. Kendall, 1989, Underground Storage Systems, Leak Detection and Monitoring, Lewis Publishers, Chelsea, Michigan.

Scintrex Earth Science Instrumentation, July 8, 1999a, "IDS Intelligent Detection Systems Corporate Website," <http://www.idsdetection.com/>, Toronto, Ontario.

Scintrex Earth Science Instrumentation, June 30, 1999b, Quotations from Scintrex Earth Science Instrumentation, Denton, Texas.

Sensors and Software, June 23, 1999a, telephone call with representative, Mississauga, Ontario.

Sensors and Software, June 21, 1999b (last updated), "PulseEKKO 100 geological system," $<$ http://www.sensoft.on.ca/geosys.htm>, Mississauga, Ontario.

Sharma, Prem V., 1997, Environmental and Engineering Geophysics, Cambridge University Press, Cambridge, Massachusetts.

Sherbert, K., July 19, 1999, fax, Geoprobe Systems, Salinas, Kansas.

Shoppach, Christi, June 24, 1999, e-mail, representative from LaCoste \& Romberg, Austin, Texas.

Silliman, John, March 3, 1999, e-mail, Technical Sales Representative, Dexsil Corporation, Hamden, Connecticut.

Skelter Imports, March 30, 1999, "Skelter Imports Inc." Chilliwack, British Columbia, Canada, $<$ http://www.skelter.ca/products.htm>.

Smalley, Jeff, March 1999, e-mail from Jeff Smalley to Joe Cruz, forwarded to me by Joe Cruz, Richland, Washington.

Smith, Bret W., June 24, 1999, e-mail, Geophysicst at GISCO, Minneapolis, Minnesota.

Smuin, David R., 1995, "Waste and Cost Reduction Using Dual Wall Reverse Circulation Drilling with Multi-Level Groundwater Sampling for Contaminant Plume Delineation," CONF-950868-33. 
Solomon, Stan, March 1999a, personal communications, Florida International University Hemispheric Center for Environmental Technology, Miami, Florida.

Soloman, Sabrie, 1999b, Sensors Handbook, McGraw-Hill, New York.

Speed, D.L., November 30, 1994, Wet/Dry/Sounding Reel Tape Final Report, WSRC-TR-940577, Westinghouse Savannah River Company, Savannah River Site, South Carolina.

SRI Instruments, May 4, 1999 (last updated), "Low Cost Gas Chromatographs and Data Systems," <http://www.srigc.com/>, Torrance, California.

Stang, John, April 7, 1997, "Hanford changing approach to waste," Tri-City Herald, Richland, Washington.

Studiecentrum voor Kernenergie - Centre d'étude de l'Energie Nucléaire (SCKCEN), 1999, "SCKCEN Inside, Research and Services: Radiation Protection," Belgium, $<$ http://www.sckcen.be/research/radiationprotection/safeguards/\#4>.

Surveyors Shop, January 19, 2000, "Magnetic Locators," The Surveyors Shop, Hackensack, New Jersey, <http://www.surveyors-shop.com/catalog/0029.htm>.

Tanks Focus Area, September 24, 1997, “OST Cost Savings Analysis-FY97,” Department of Energy, Tanks Focus Area, Richland, Washington.

Tanks Focus Area, July 30, 1998a, "OST Cost Savings Analysis-FY98, Borehole miner, extendible nozzle system," Department of Energy, Tanks Focus Area, Richland, Washington.

Tanks Focus Area, May 8, 1998b, “Tank Focus Area, Raman Probe and Cone Penetrometer Deployment System," <http://www.pnl.gov/tfa/tech/char/ram_cp.html $>$, Department of Energy, Tanks Focus Area, Richland, Washington.

Tansony, R., May 15, 2000, e-mail, Markland Specialty Engineering Ltd., Toronto, Ontario, Canada.

Technos, Inc., March 11, 1999 (last updated), “Technotes, characterization of fractured rock and karst conditions," <http://technos-inc.com/TECHKARS.HTM>, Miami, Florida.

Thomas, Graham, April 1995, Overview of Nondestructive Evaluation Techniques, UCRL-JC120505, presentated at the SPIE Nondestructive Evaluation of Aging Infrastructure Conference at Oakland, California, June 6-8, 1995.

Thompson Machinery Commerce Corporation, 1999, "Thompson Used Equipment," <http:// www.thompsonmachinery.com/equip.nsf/Used+Equipment $>$, Nashville, Tennessee.

Thornton, Ed, March 1999, e-mail from Ed Thornton to Joe Cruz, forwarded to me by Joe Cruz, Richland, Washington.

Tyler, Scott W., Bridget R. Scanlon, Glendon W. Gee, and Graham B. Allison, 1999, "Water and Solute Transport in Arid Vadose Zones," Chapter 13 in Vadose Zone Hydrology, ed. Marc B. Parlange and Jan W. Hopmans, Oxford University Press, New York, New York.

Wade, C.D., June 1997, Technical Basis for the Performance of Radiological Surveys in Support of Nuclear Facility Decommissioning/Deactivation Utilizing the Laser-Assisted Ranging and Data System (LARADS), BHI-01038, prepared for the DOE, Office of Environmental Restoration by Bechtel Hanford, Inc., Richland, Washington. 
Washington Administrative Code 173-303-807, Olympia, Washington.

Waste Policy Institute (WPI), February 1999, "RCI - Getting More Bang for the Demonstration Buck," Initiatives Online, Volume 4, $<$ http://www.wpi.org/initiatives/init/feb97/index.htm>, Waste Policy Institute, Virginia Polytechnic Institute University, Arlington, Virginia.

Webster, D.A., 1996, Results of Ground-Water Tracer Tests Using Tritiated Water at Oak Ridge National Laboratory, Tennessee, Water-Resources Investigations Report 95-4182, U.S. Geological Survey, prepared in cooperation with the DOE, Nashville, Tennessee.

Westinghouse Hanford Corporation (WHC), February 21, 1995, Technical Bases for the Leak Detection Surveillance of Waste Storage Tanks, WHC-SD-WM-TI-573, Rev. 1, Richland, Washington.

Westinghouse Savannah River Company (WSRC), 1999, "Use of a Sensitive Gamma Assay Instrument for Classification of Waste in a Plutonium Stabilization Facility," Aiken, South Carolina, <http://www.srs.gov/general/scitech/fulltext/ms9900136/ms9900136.html $>$.

Wyatt, D.E., Cumbest, R.J., Aadland, R.K., Syms, F.H., Stephenson, D.E., Sherrill, J.C., June, 1997, Upper Three Runs Watershed A/M Area Advanced Geological Study Pat 1 of 3 Investigation on the Combined Use of Ground Penetration Radar, Cone Penetrometer and High Resolution Seismic Data for Near Surface and Vadose Zone Characterization in the A/M Area of the Savannah River Site, South Carolina (U), WSRC-RP-97-0184, Westinghouse Savannah River Company, Aiken, South Carolina.

Yahoo!, 2000, "Manco Go Karts by aBrands," Yahoo! Shopping, $<$ http://stores.yahoo.com/mancogokarts/index.html>. 